\title{
Unusual Tandem Alkynylation and trans-Hydrosilylation to Form Oxasilacyclopentenes
}

\author{
Sarah V. Maifeld and Daesung Lee* \\ Department of Chemistry, University of Wisconsin, \\ Madison, WI 53706 \\ dlee@chem.wisc.edu
}

\section{Supporting Information}

Table of Contents:

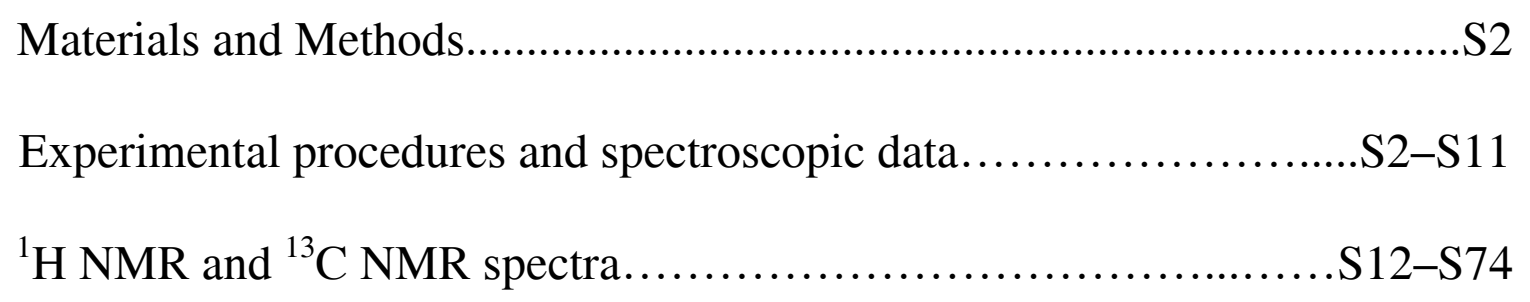




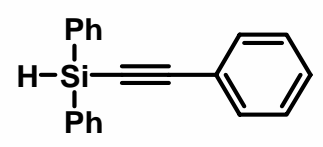

Compound 4b

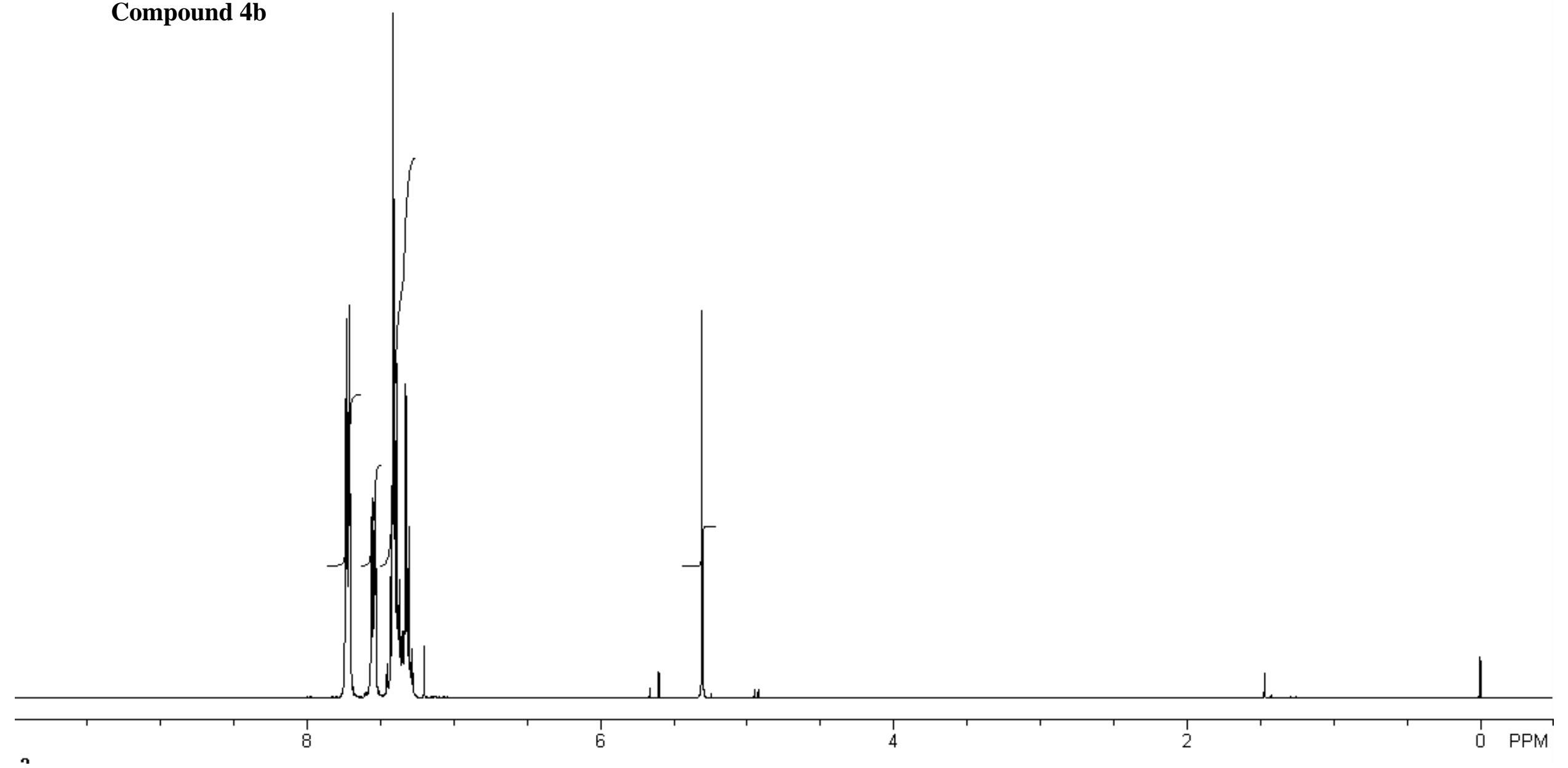




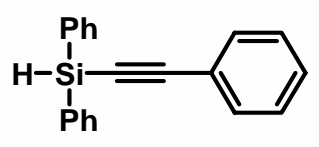

Compound 4b 


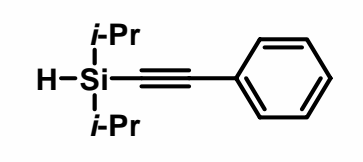

Compound 4c

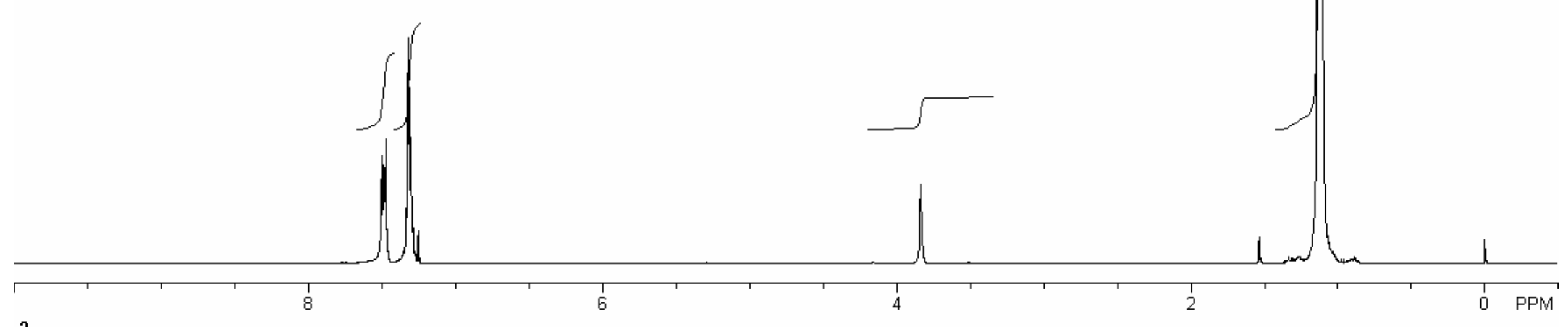




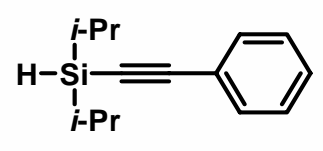

Compound 4c

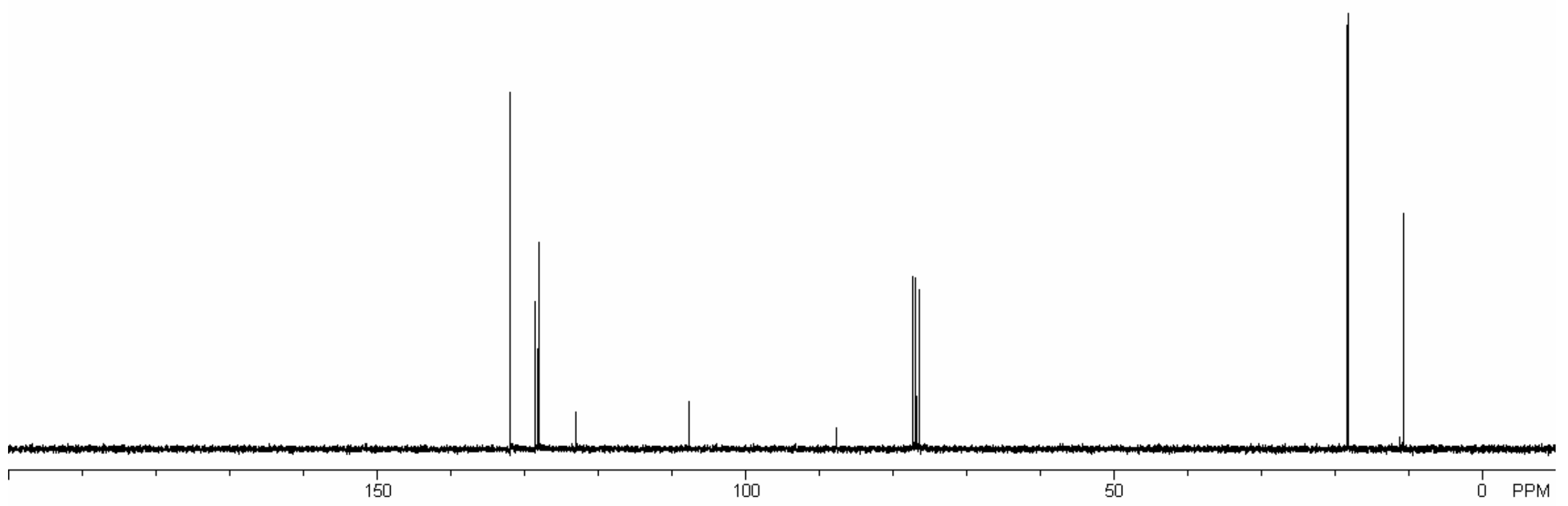




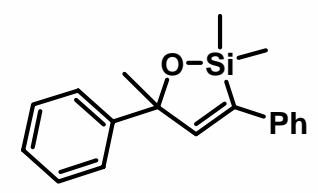

Compound 6

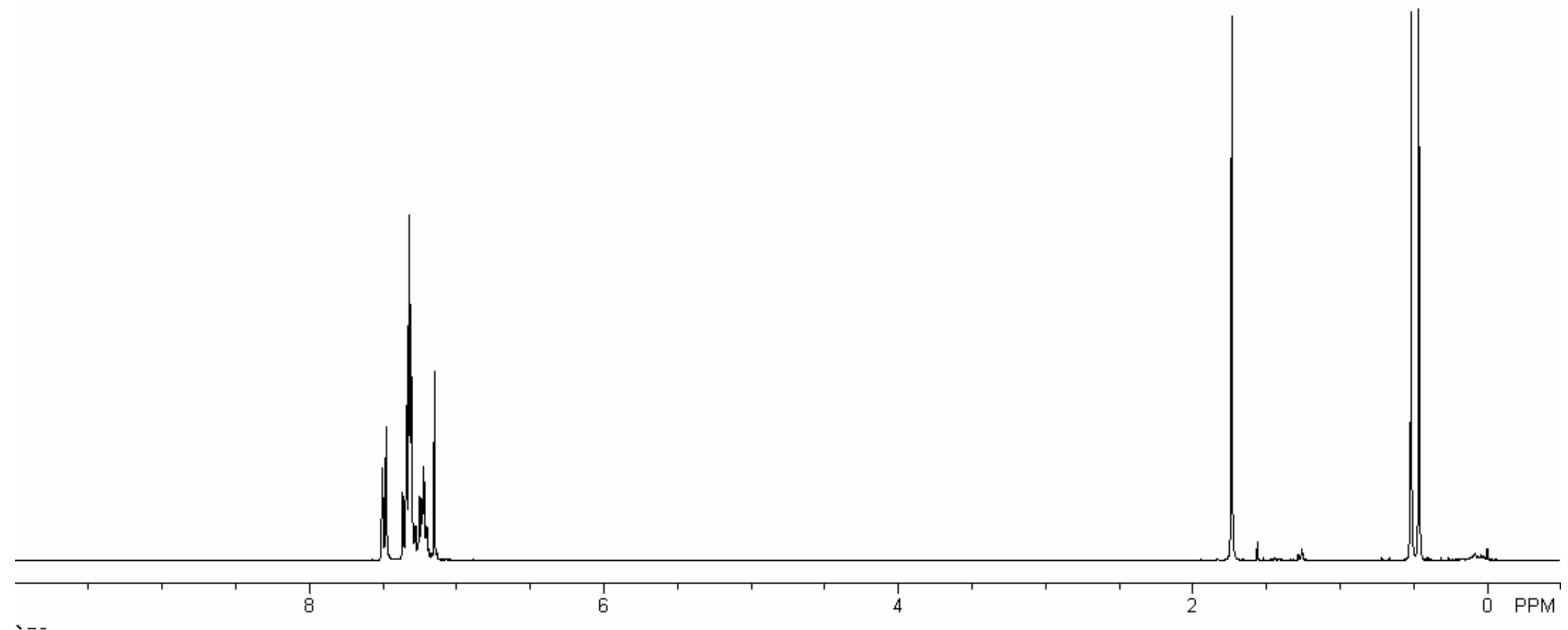

S17 


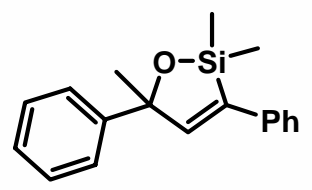

\section{Compound 6}

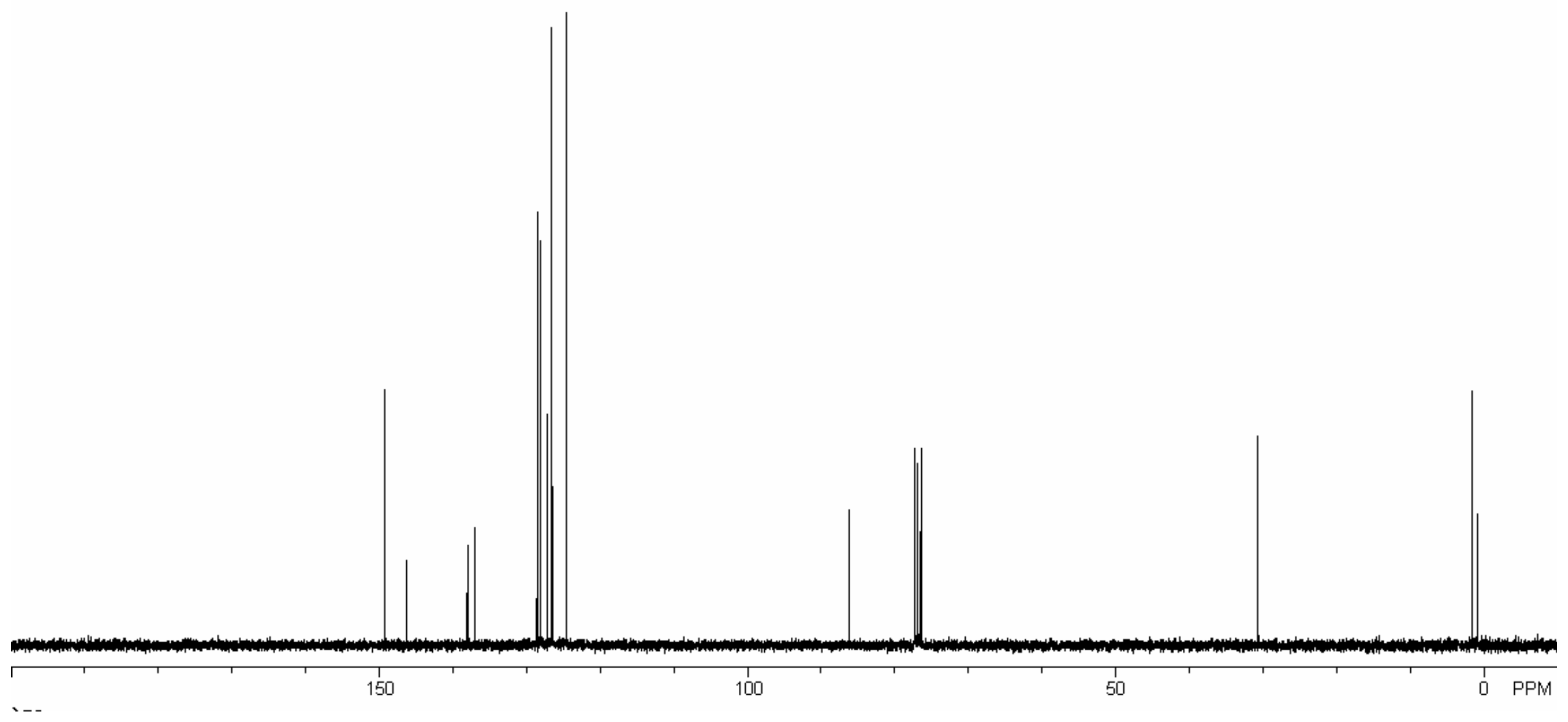




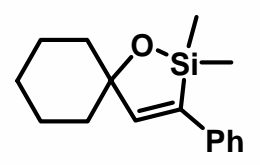

Compound 7a

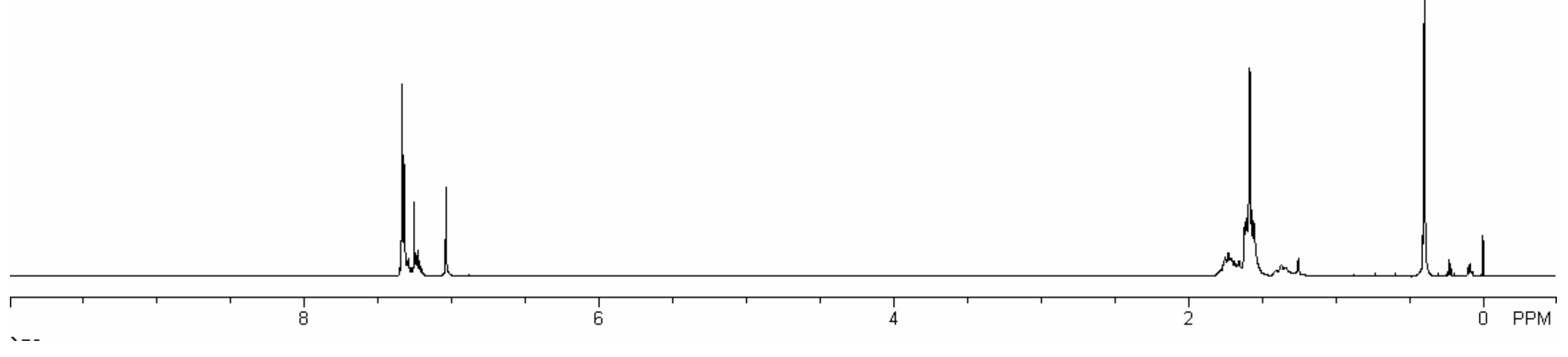




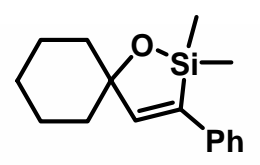

Compound 7a

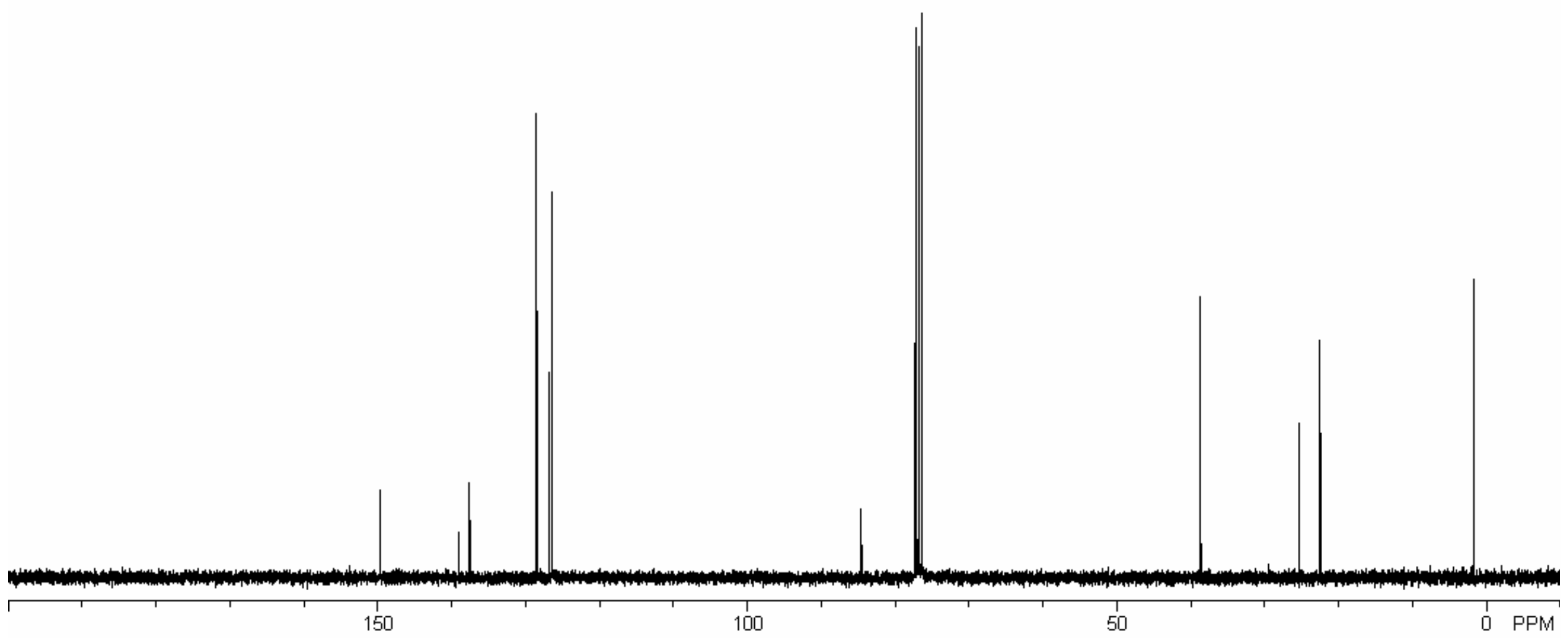




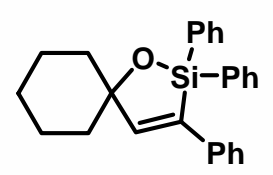

Compound 7b

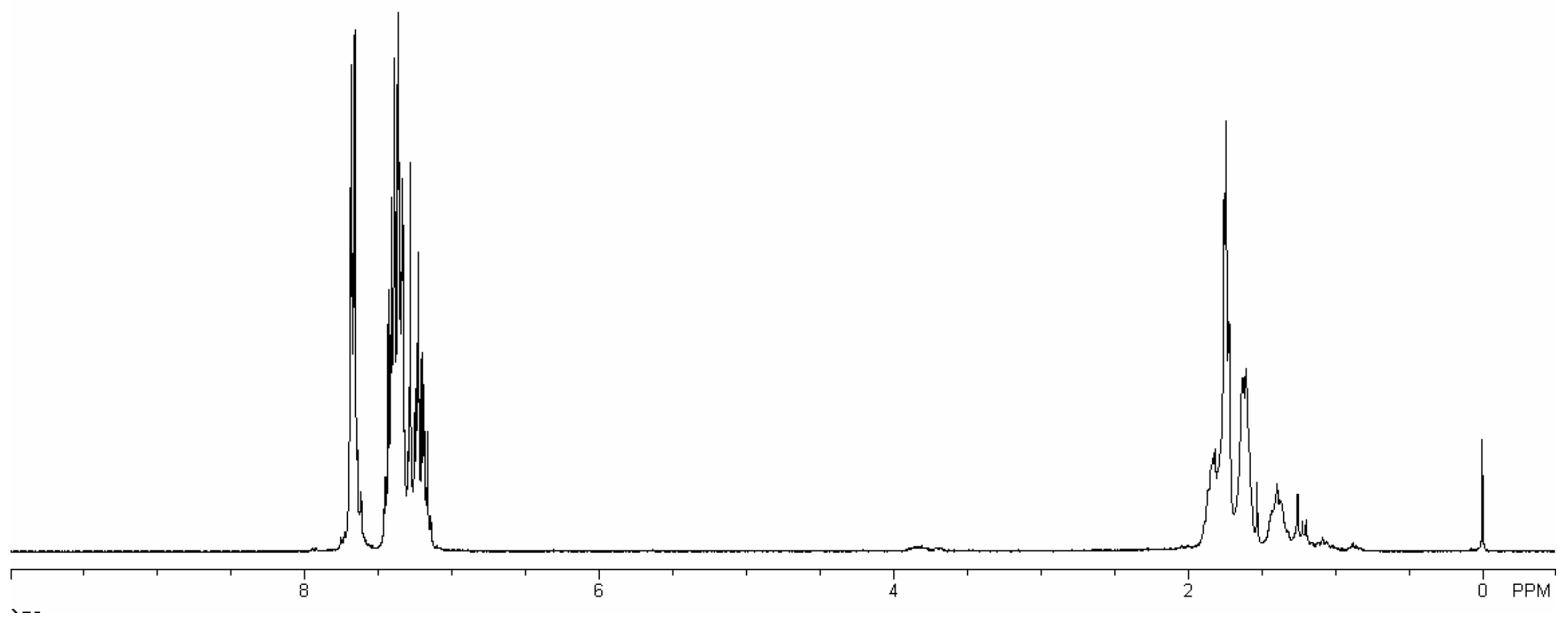

S21 


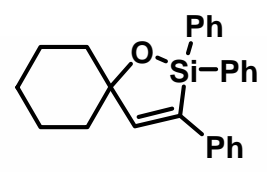

Compound 7b

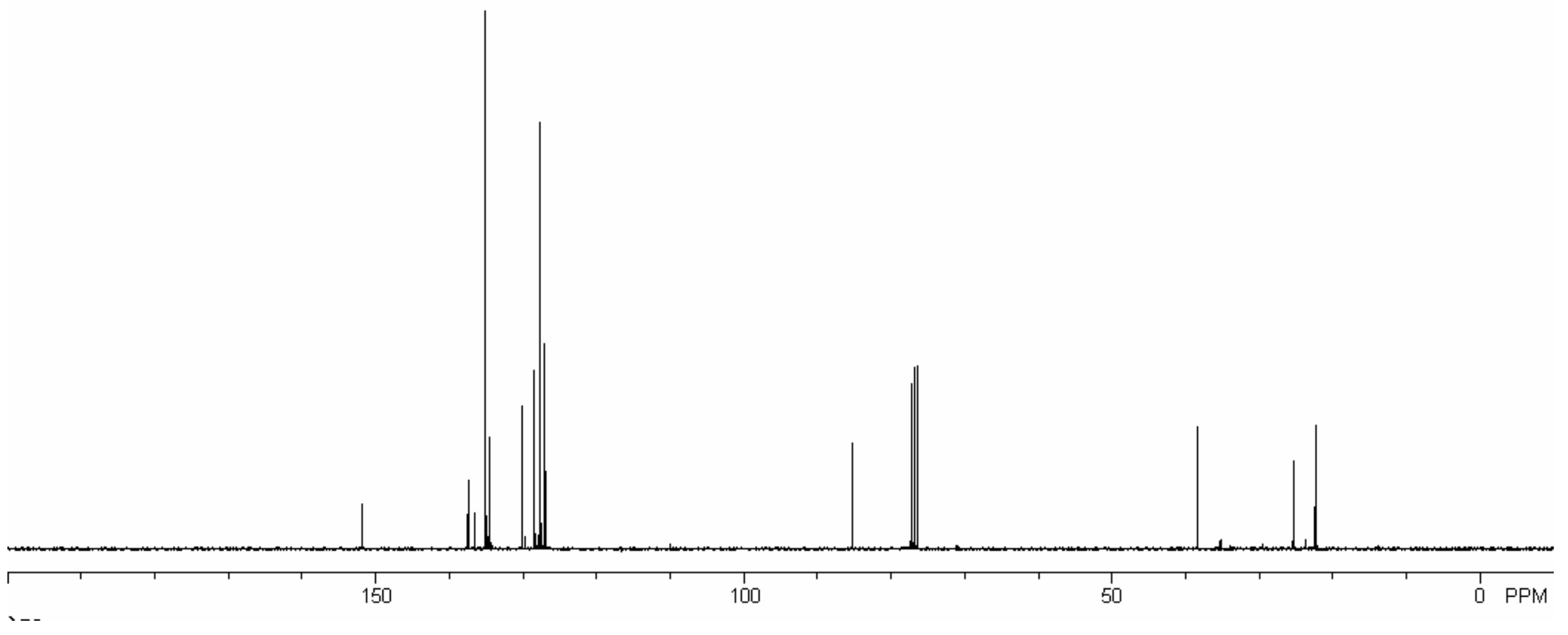




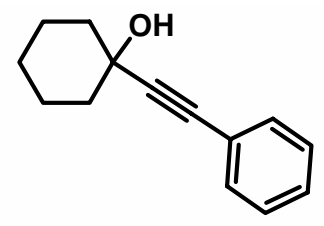

Compound 8

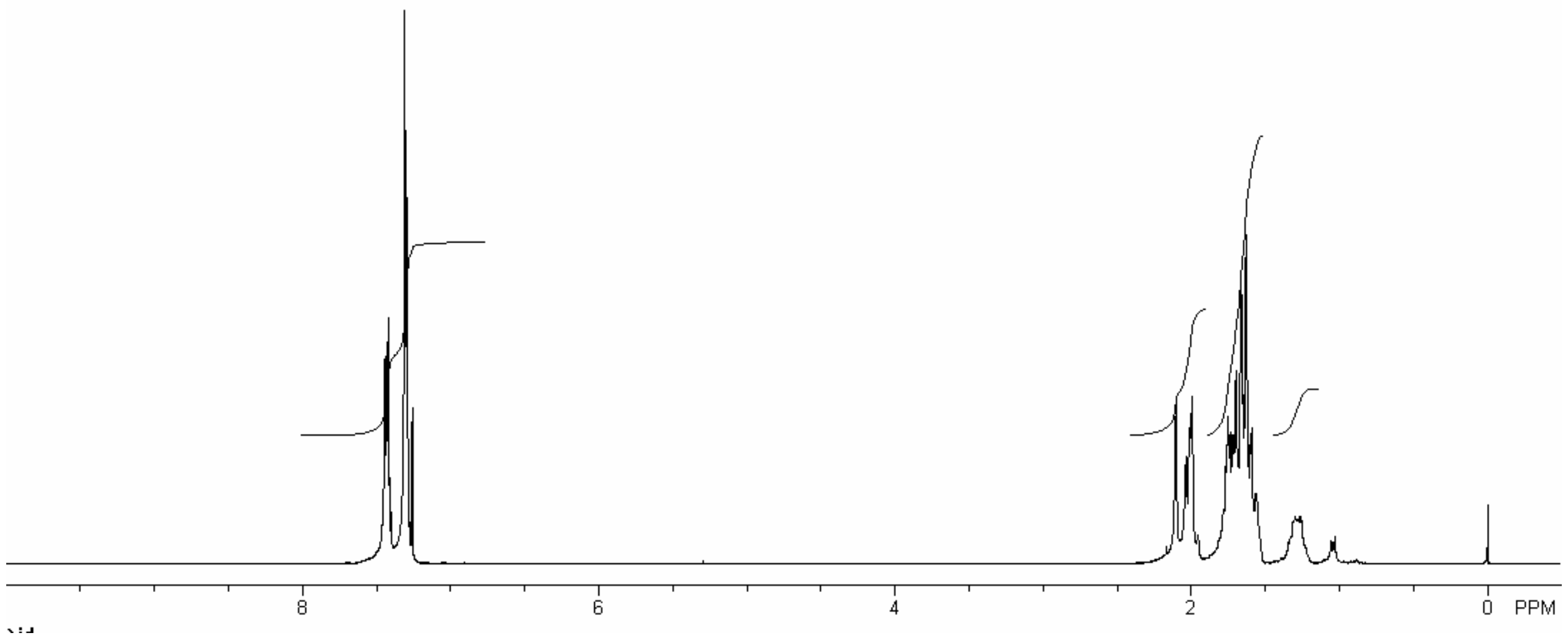

S23 


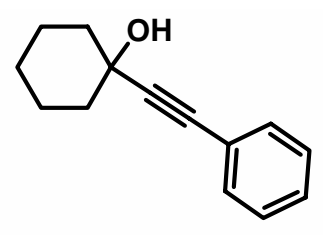

Compound 8

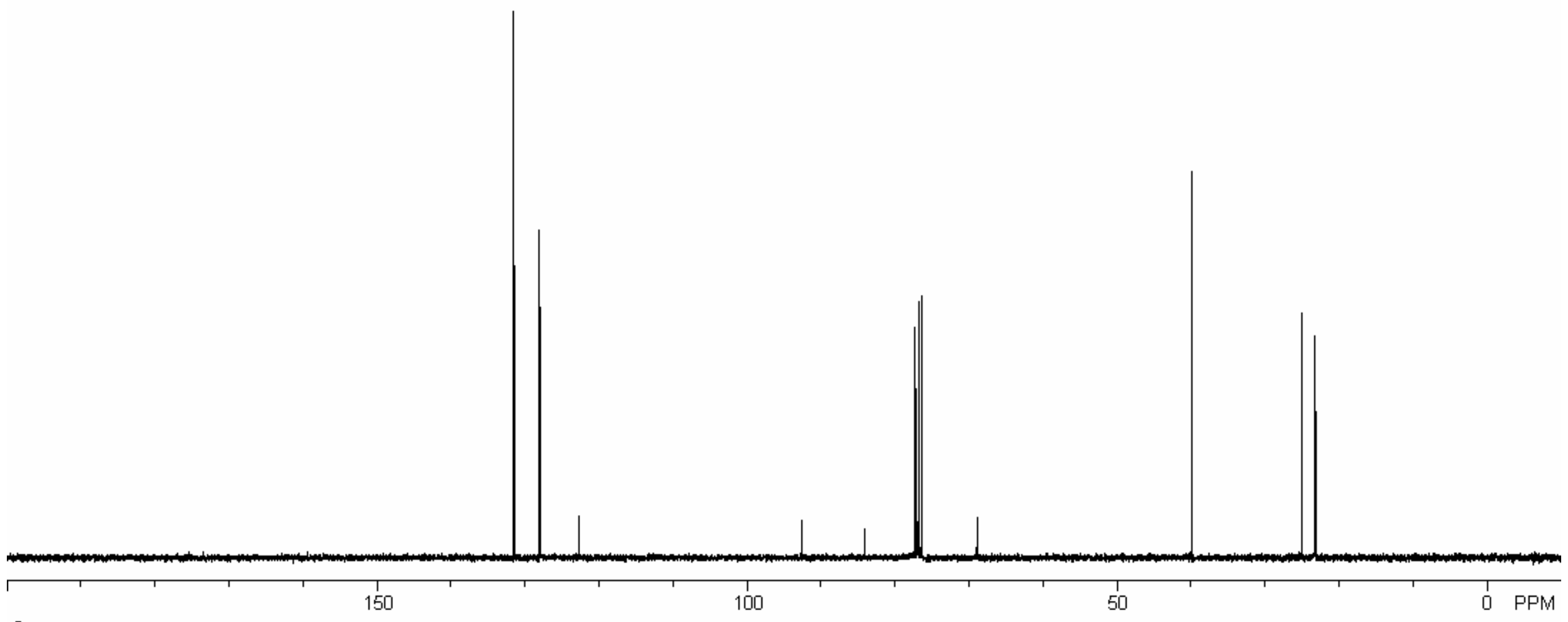




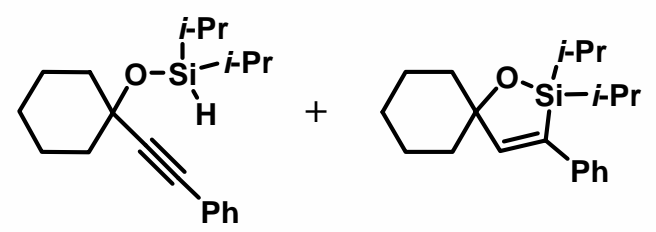

Compound 9c present with a trace amount of 7c

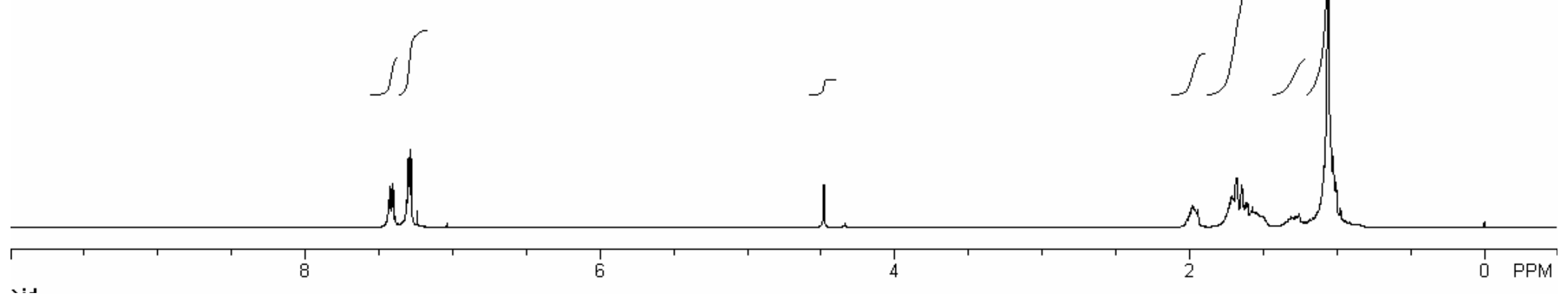




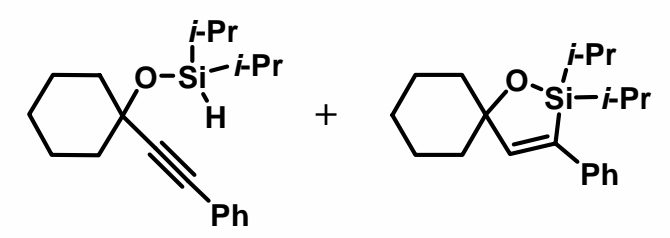

Compound 9c present with a trace amount of 7c

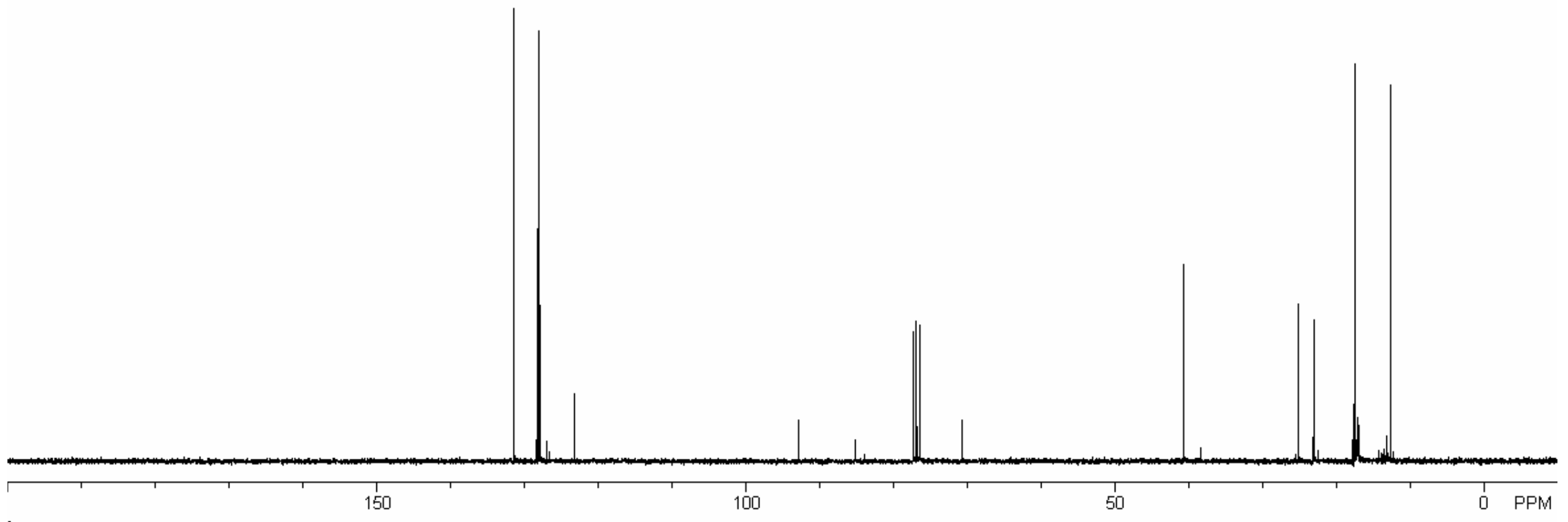




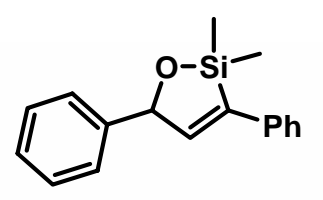

\section{Compound 11a}

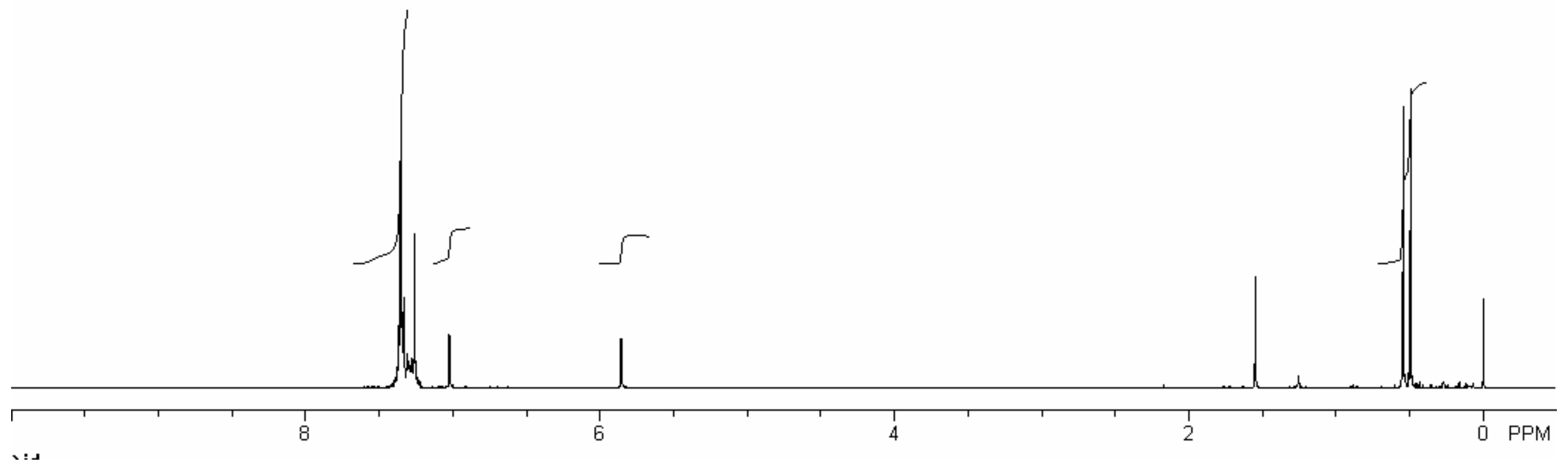




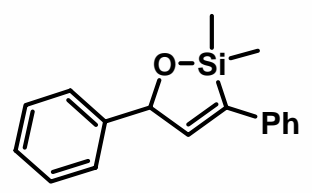

Compound 11a

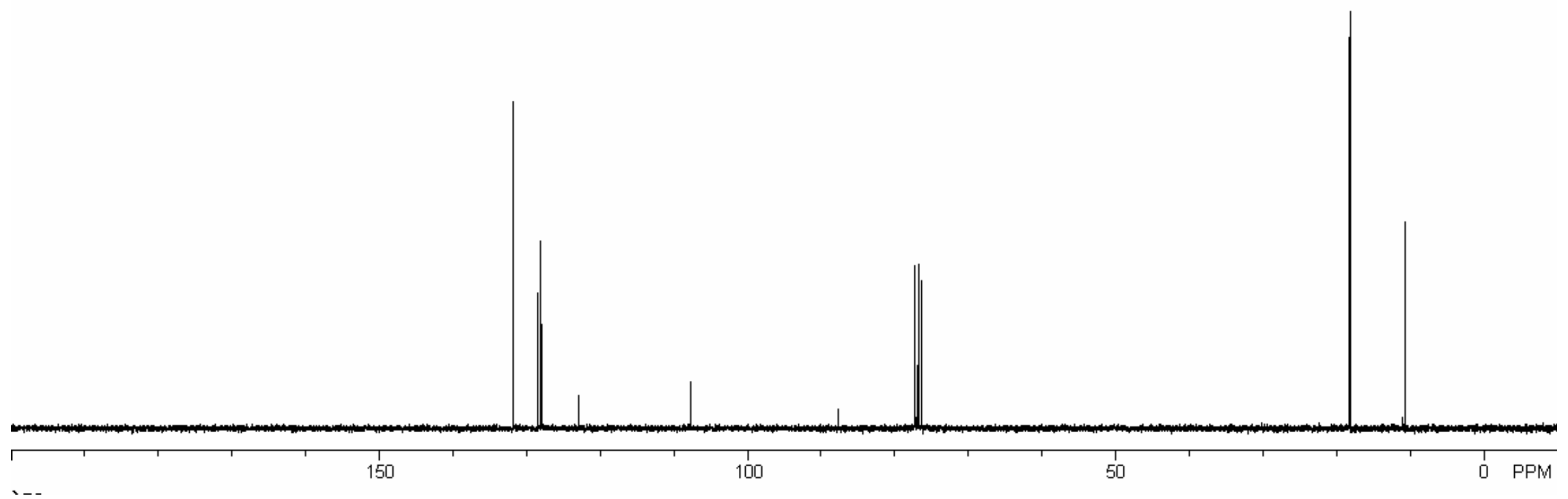




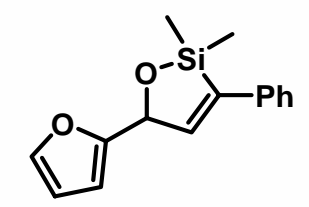

Compound 11b

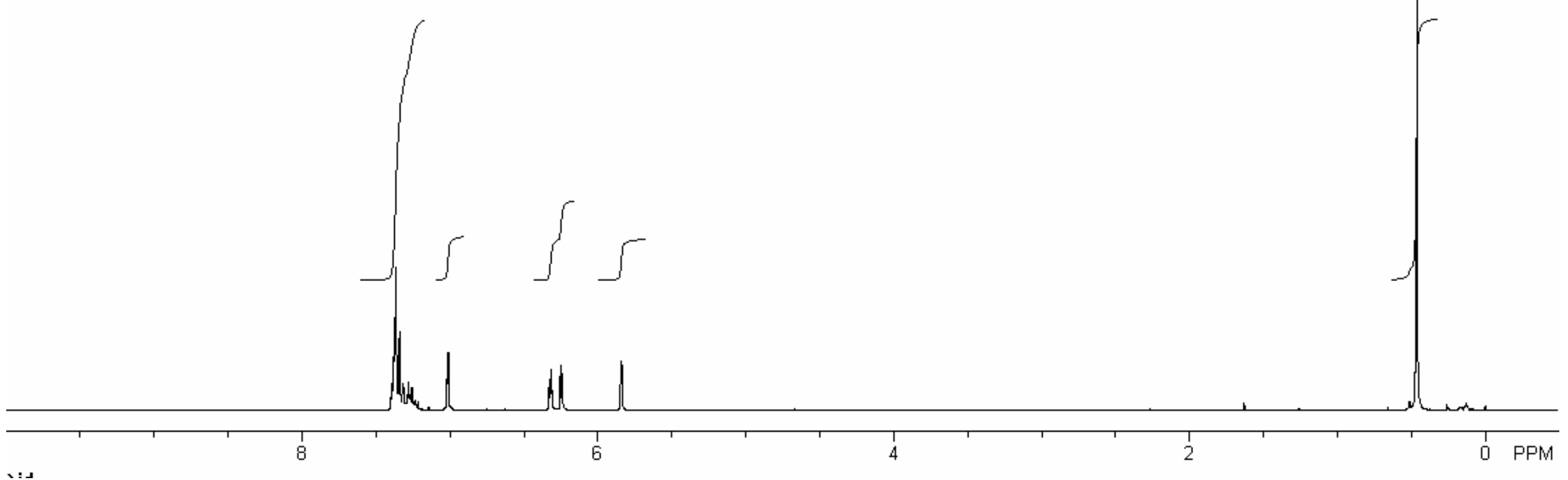




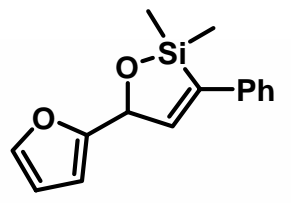

Compound 11b

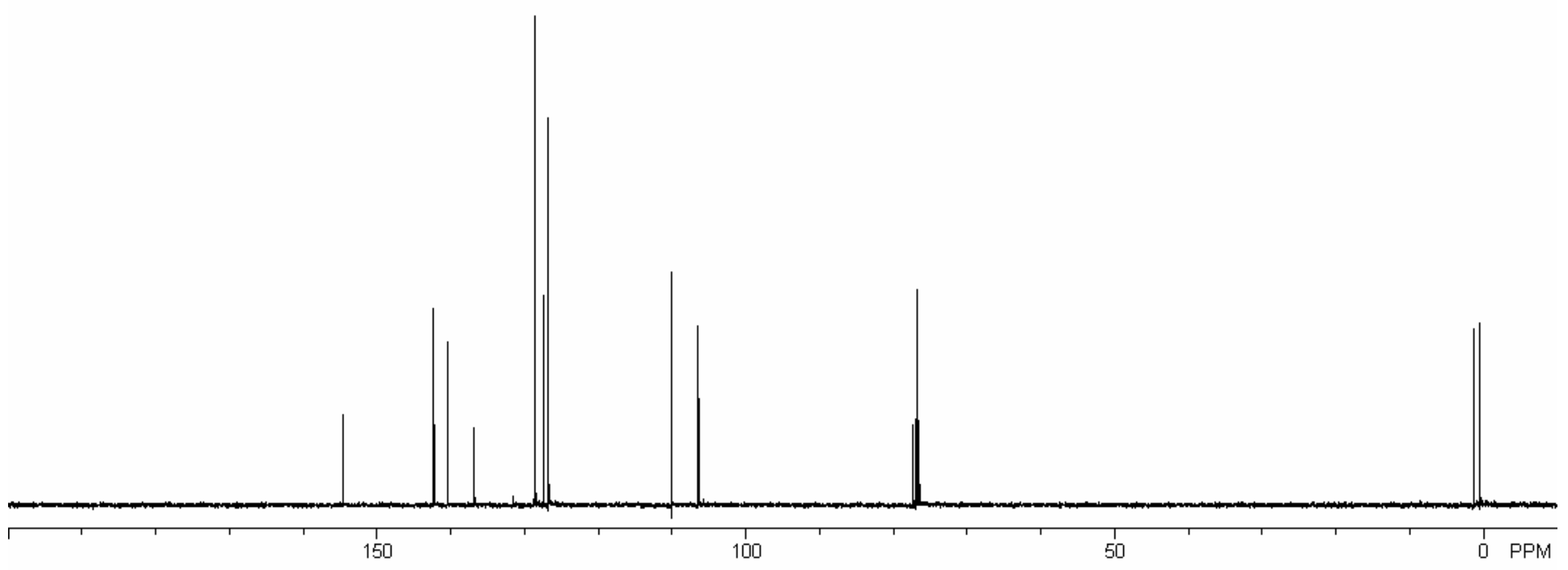




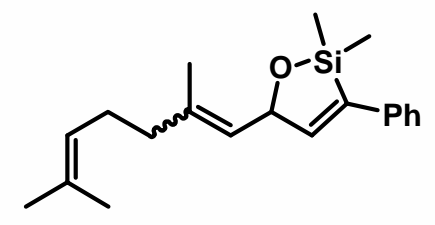

Compound 11c (1.3 : 1 E/Z mixture)

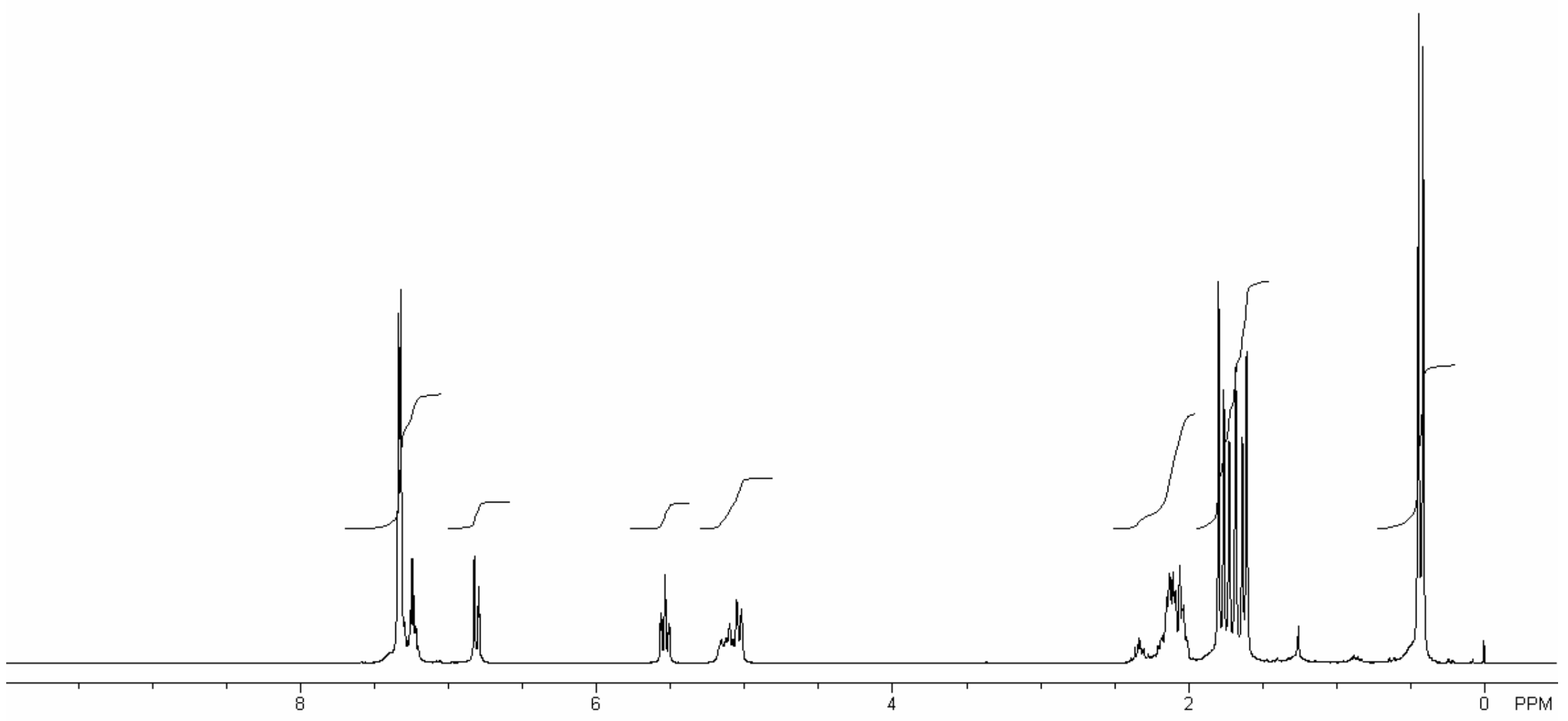




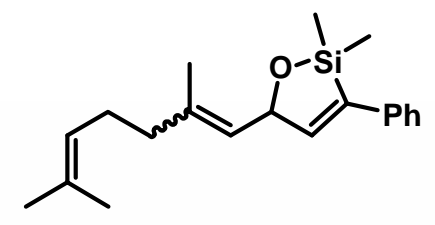

Compound 11c (1.3 : 1 E/Z mixture)

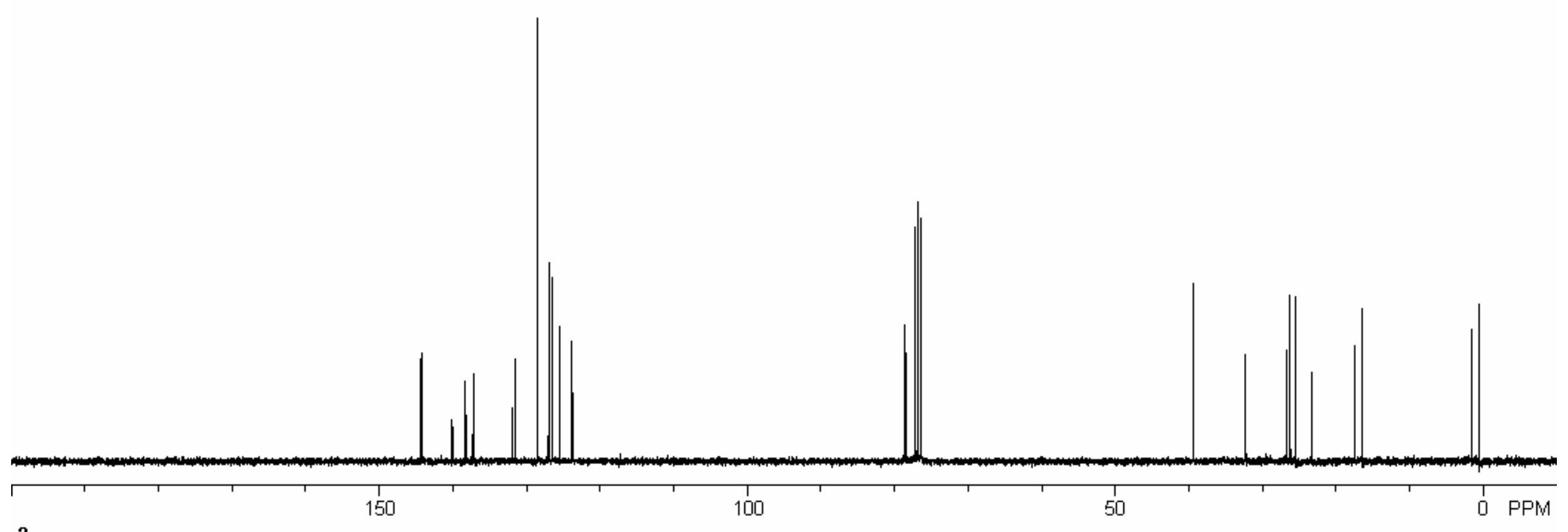




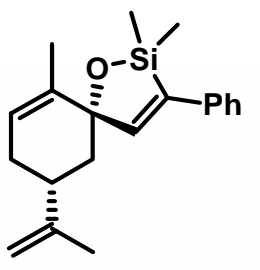

Compound 11d and minor diastereomer

(3.3 : 1 inseparable mixture of diastereomers)

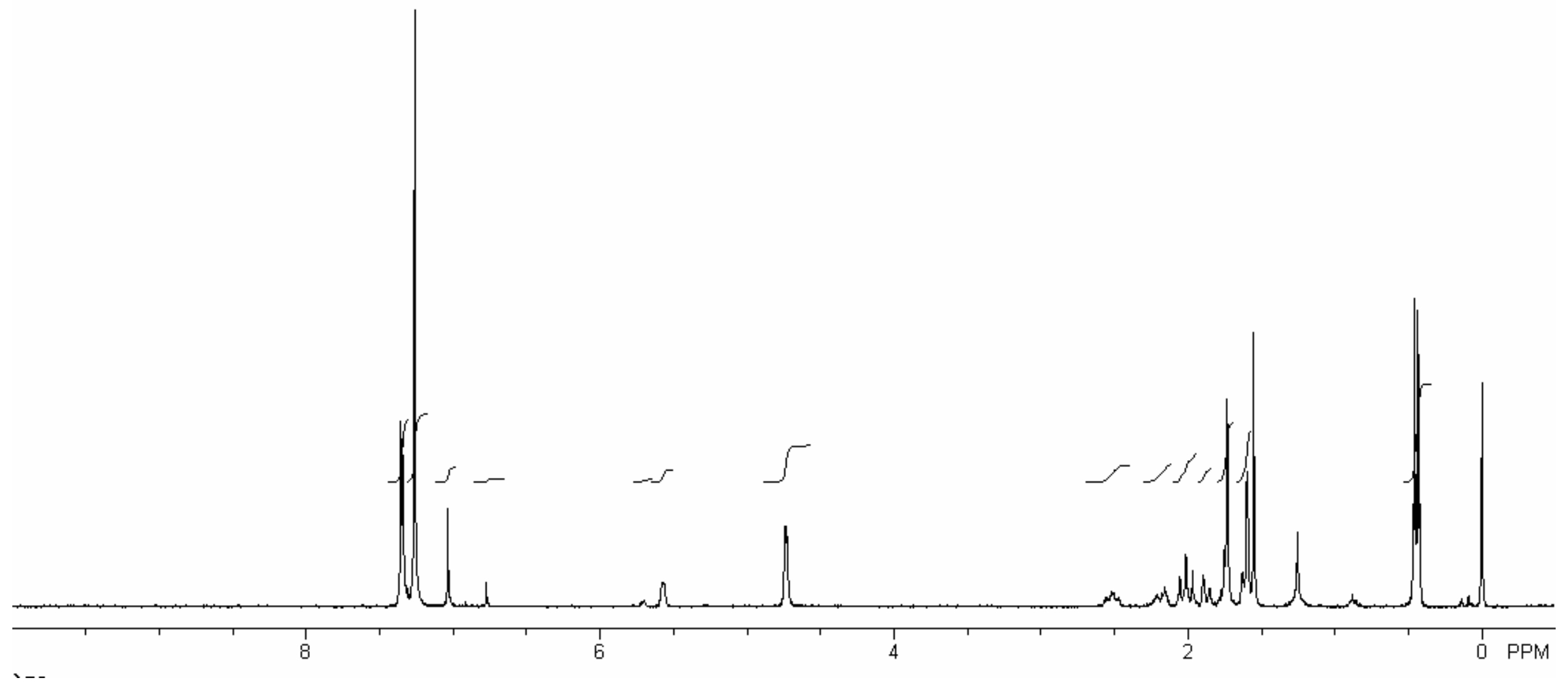




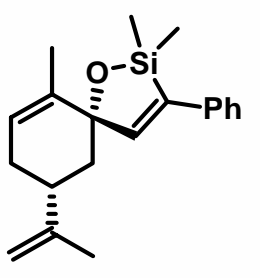

Compound 11d and minor diastereomer

(2.2: 1 inseparable mixture of diastereomers)

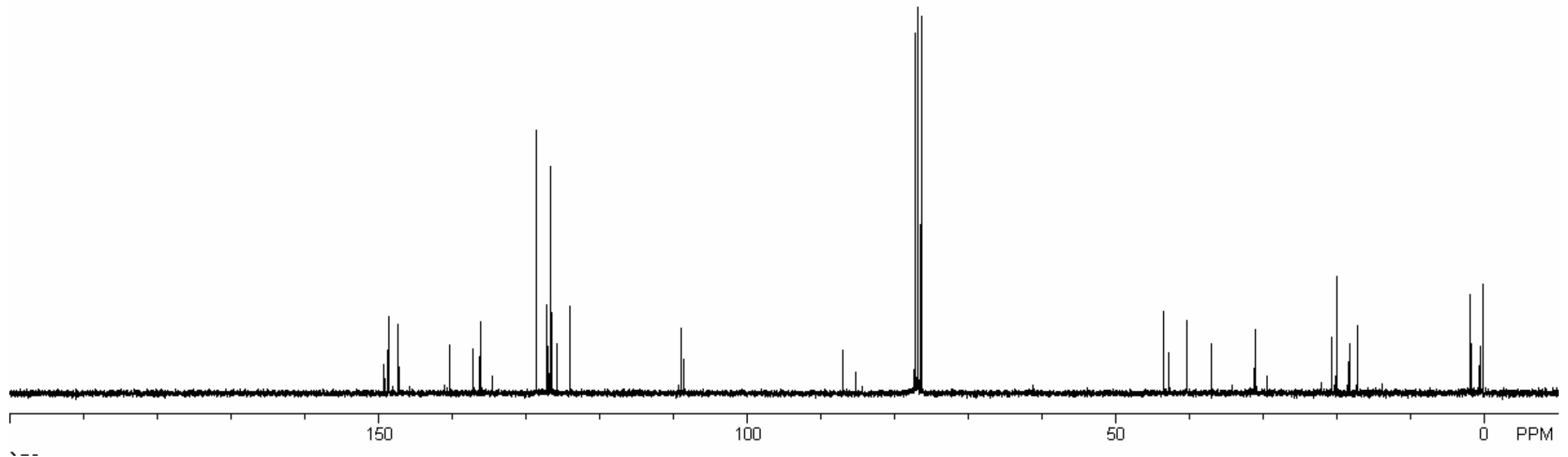




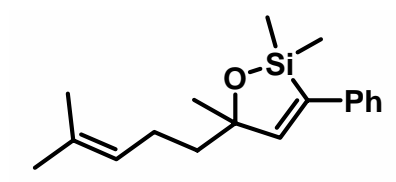

\section{Compound 11e}

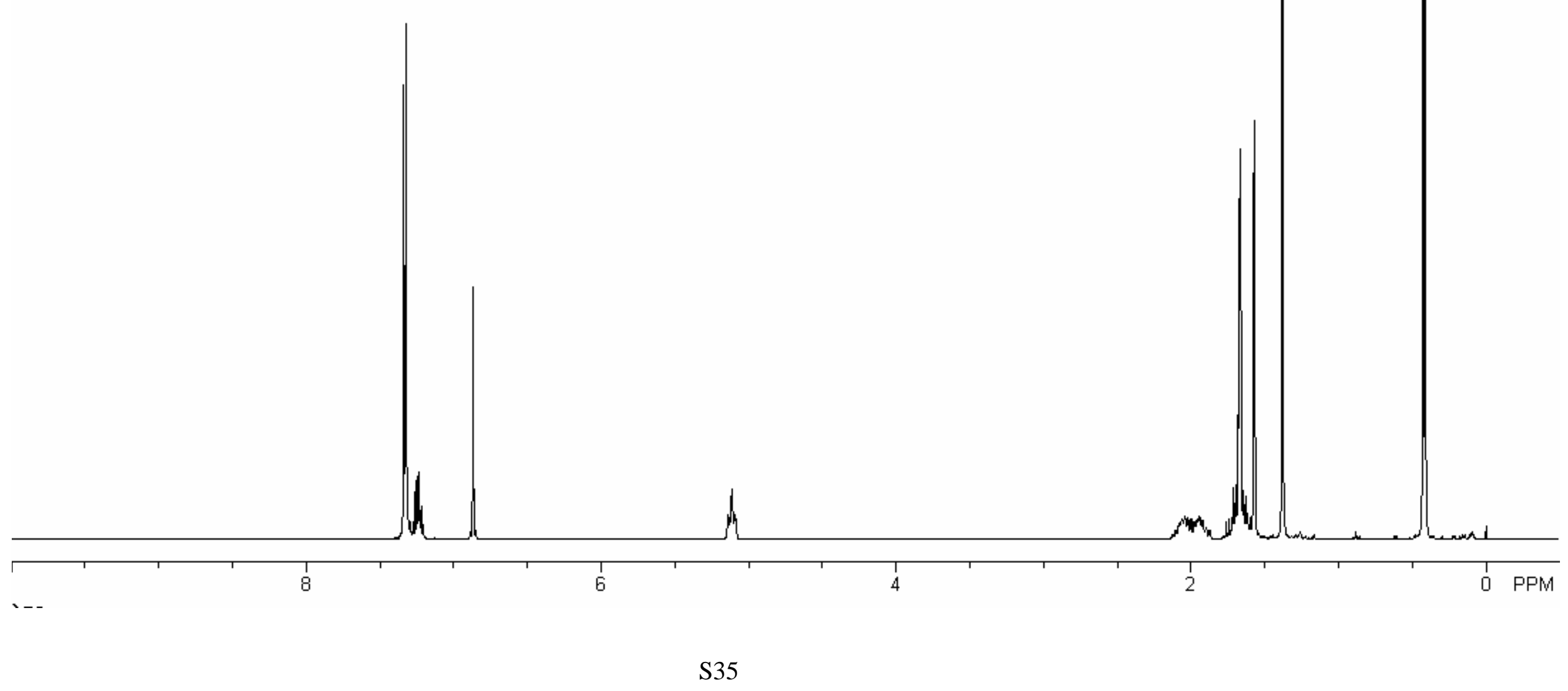




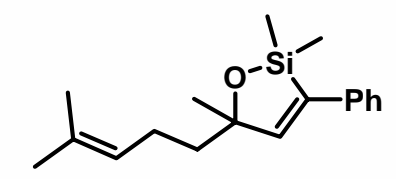

Compound 11e

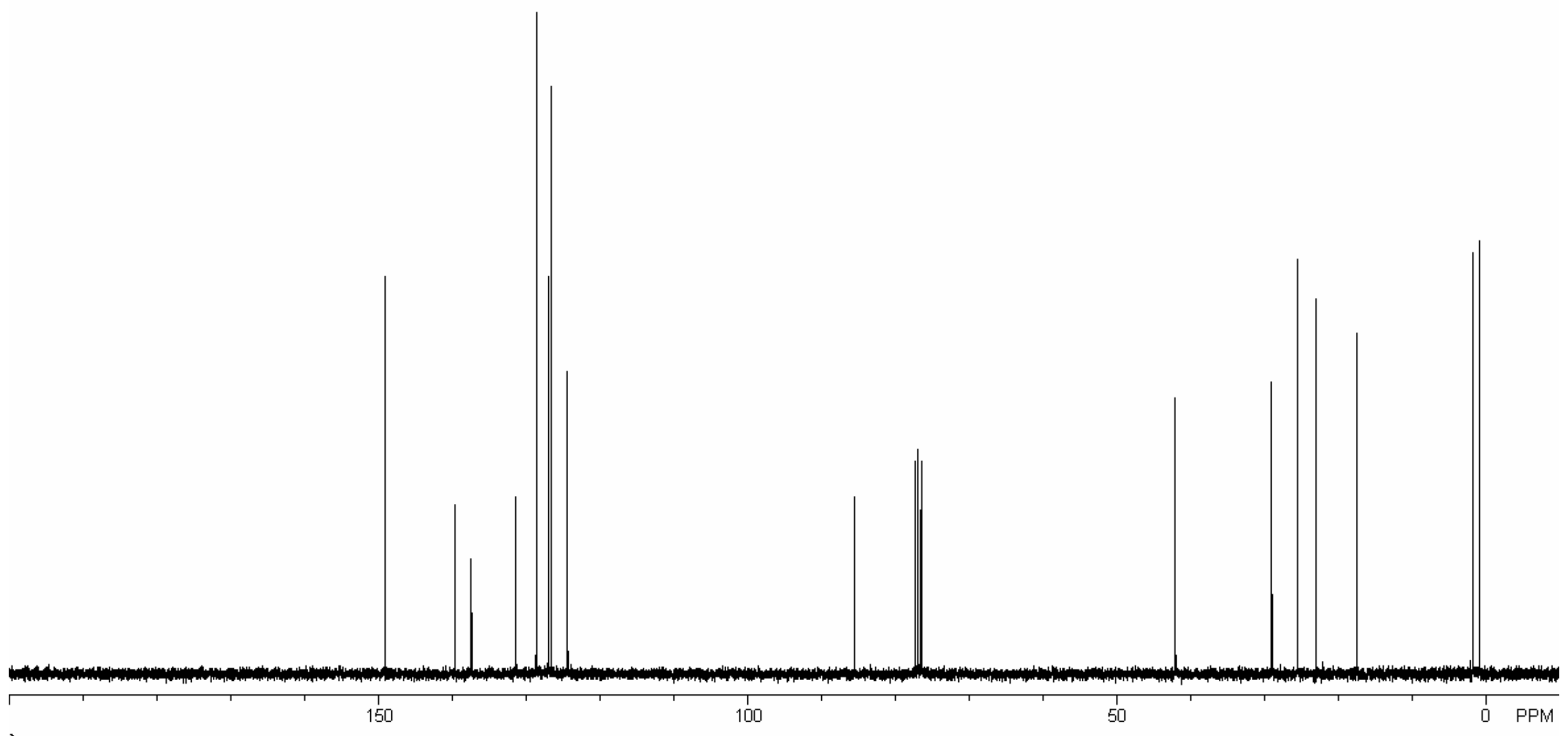




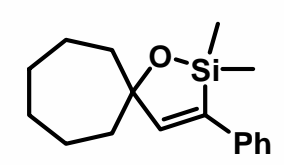

Compound 11f

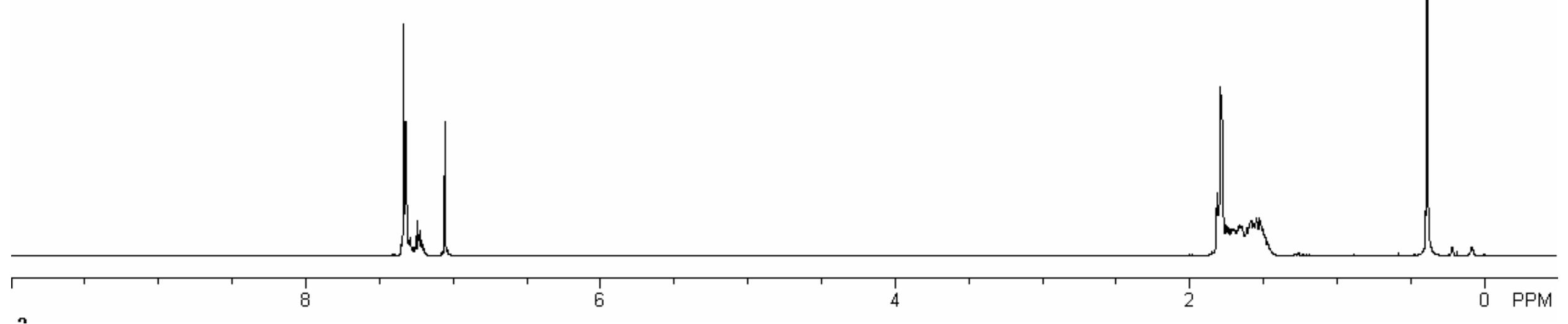




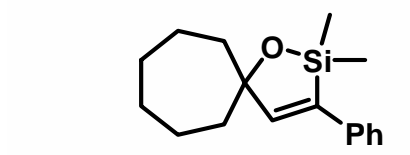

Compound 11f

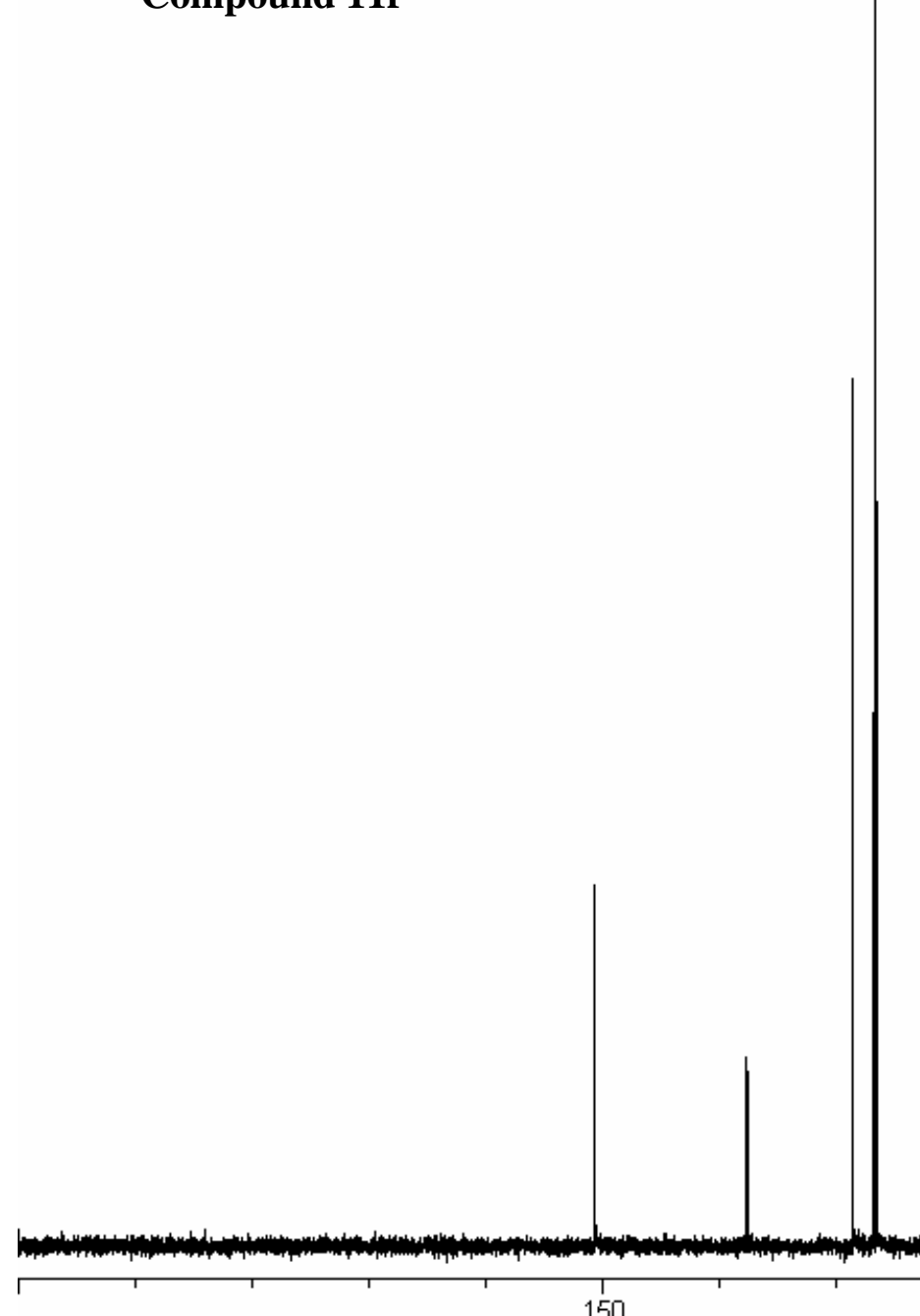

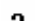




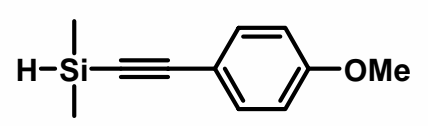

Compound 12a

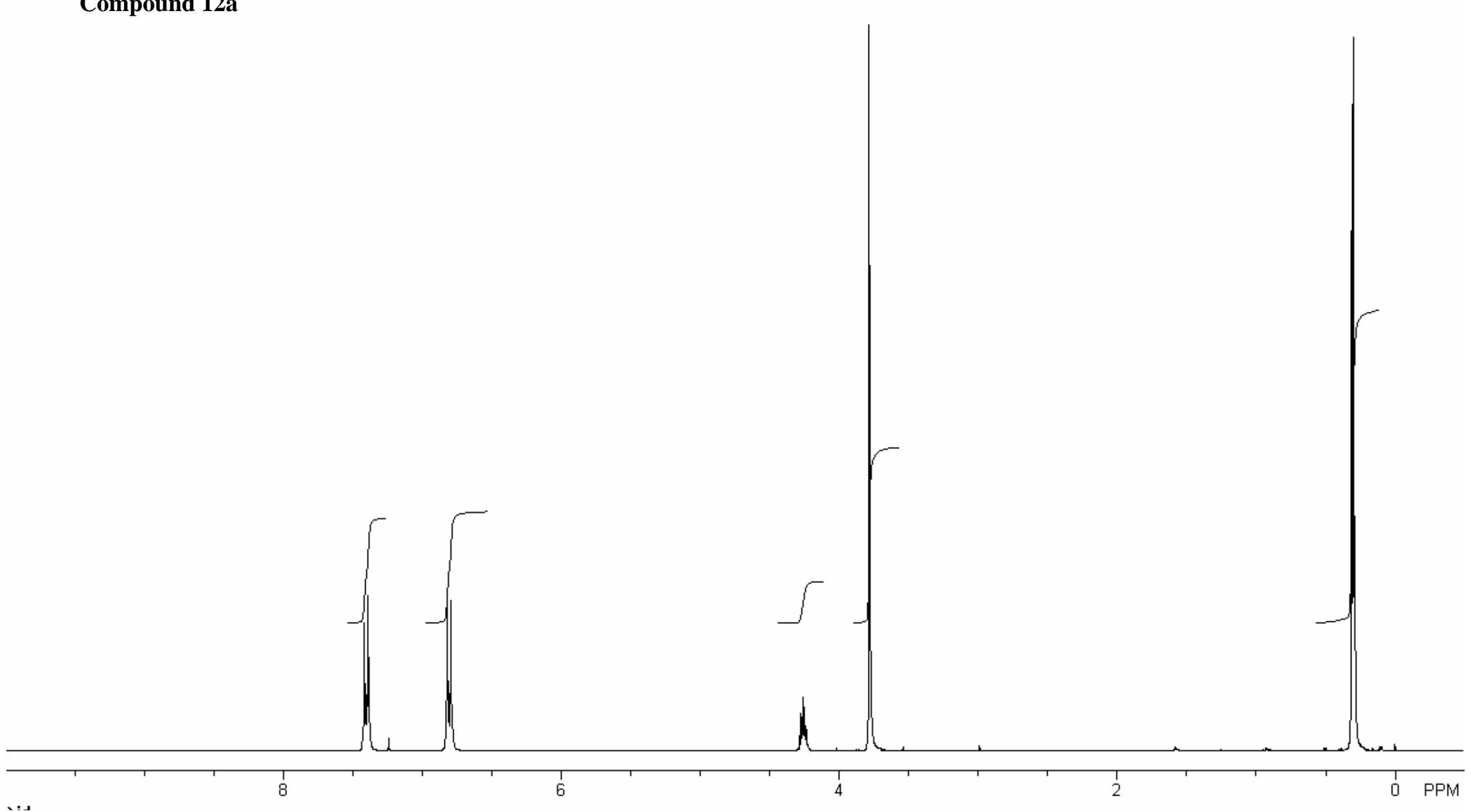


$\stackrel{\mathrm{Si}}{\mathrm{H}}=$

Compound 12a

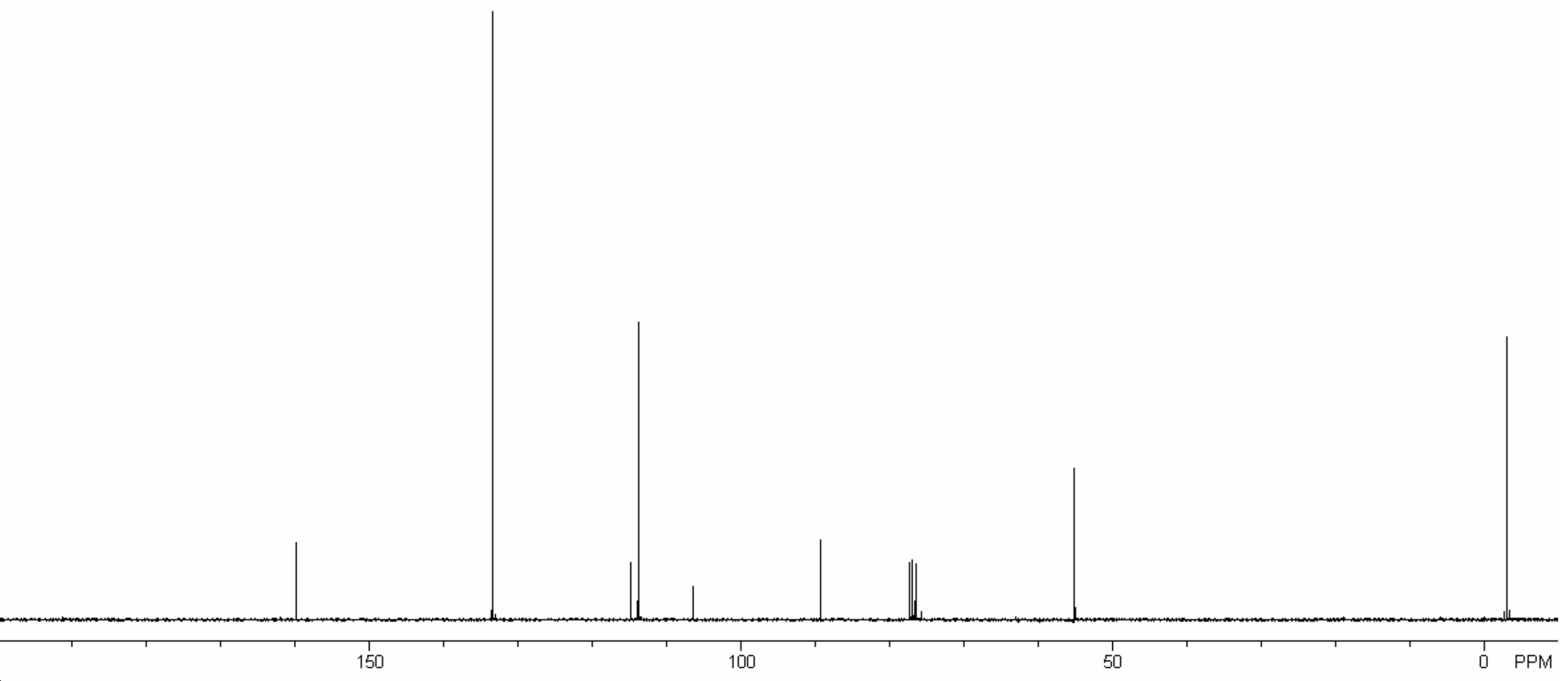




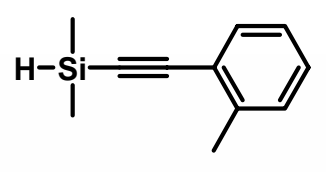

Compound 12b

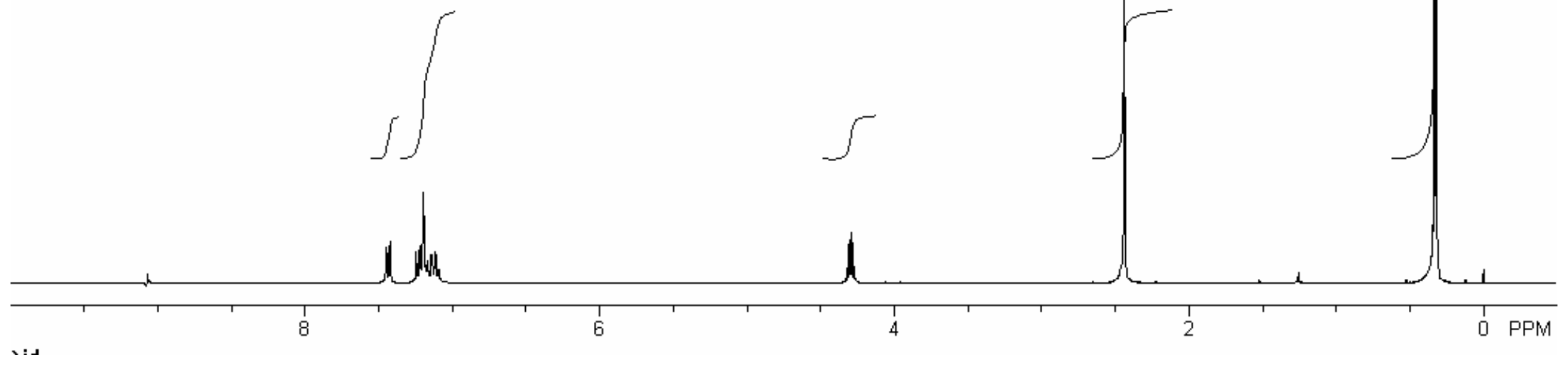


$\stackrel{1}{\mathrm{H}-\mathrm{si}}=\longrightarrow$

Compound 12b

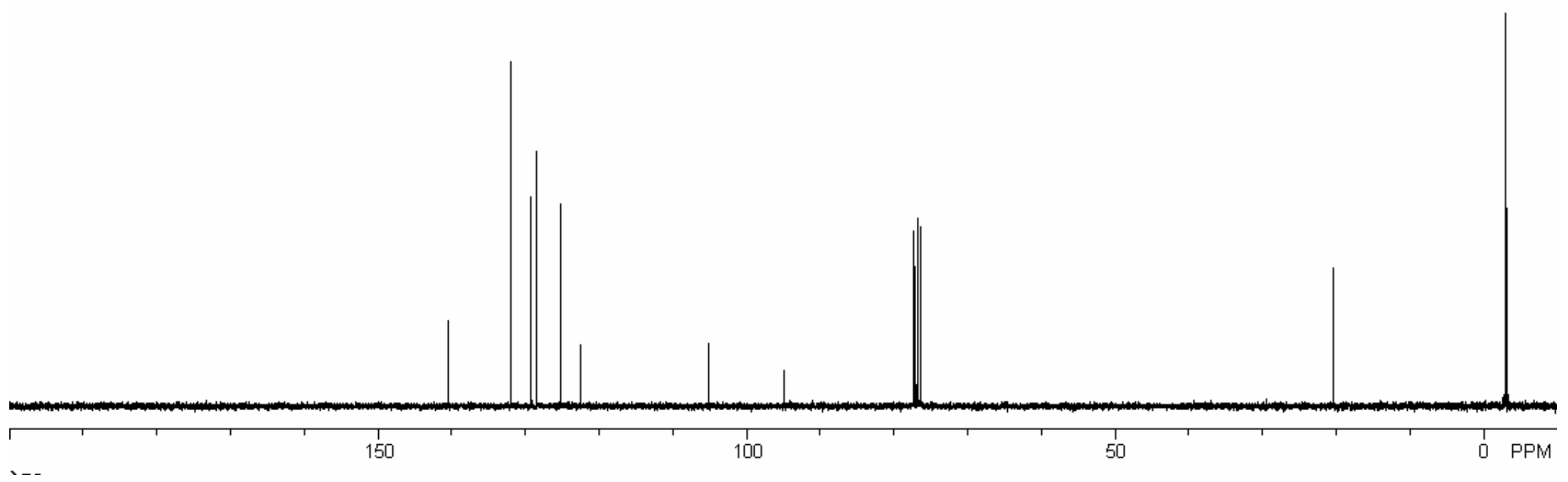




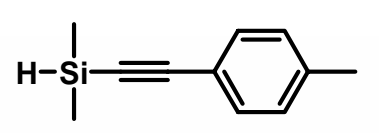

Compound 12c

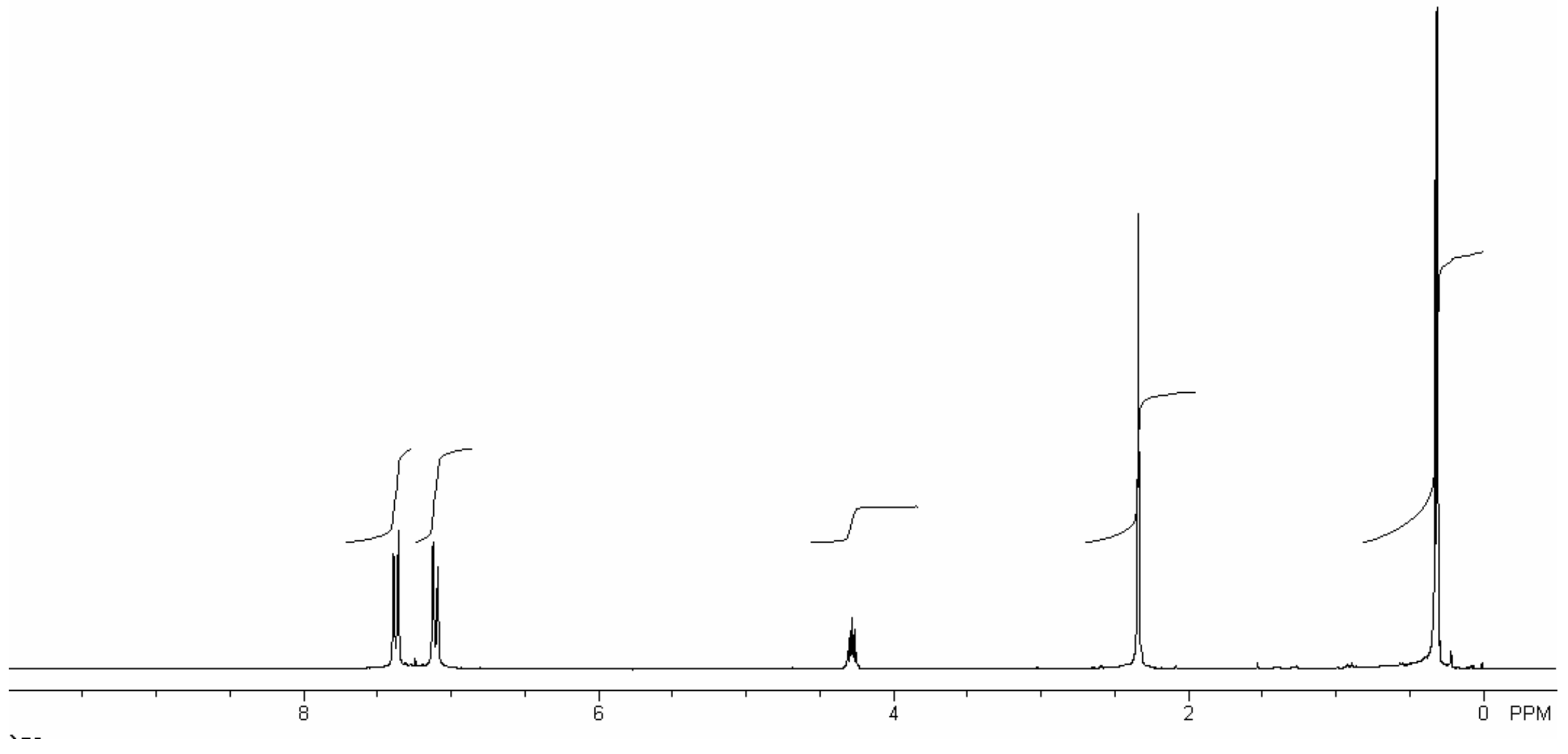


$\stackrel{1}{\mathrm{Hi}}=$

Compound 12c

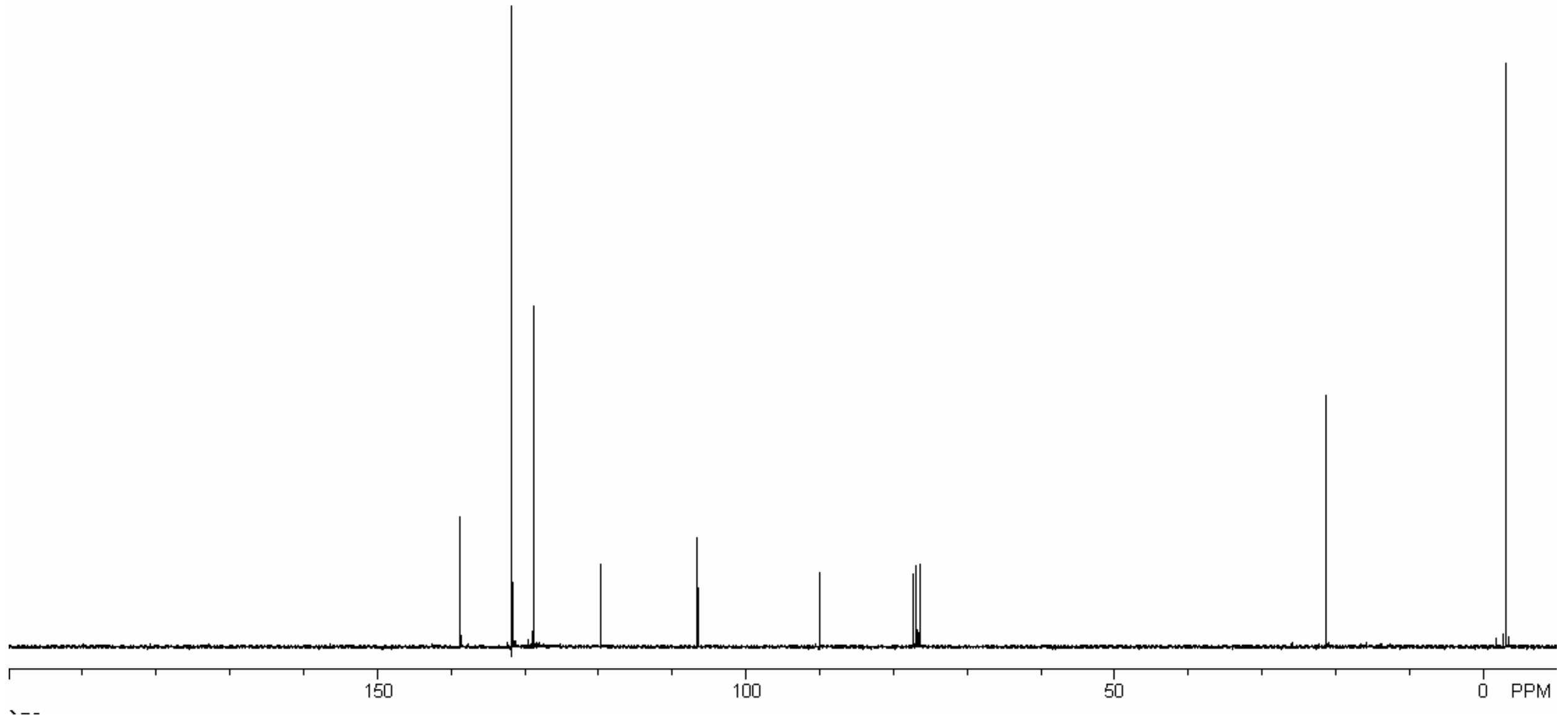




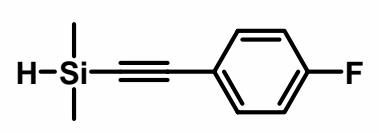

Compound 12d

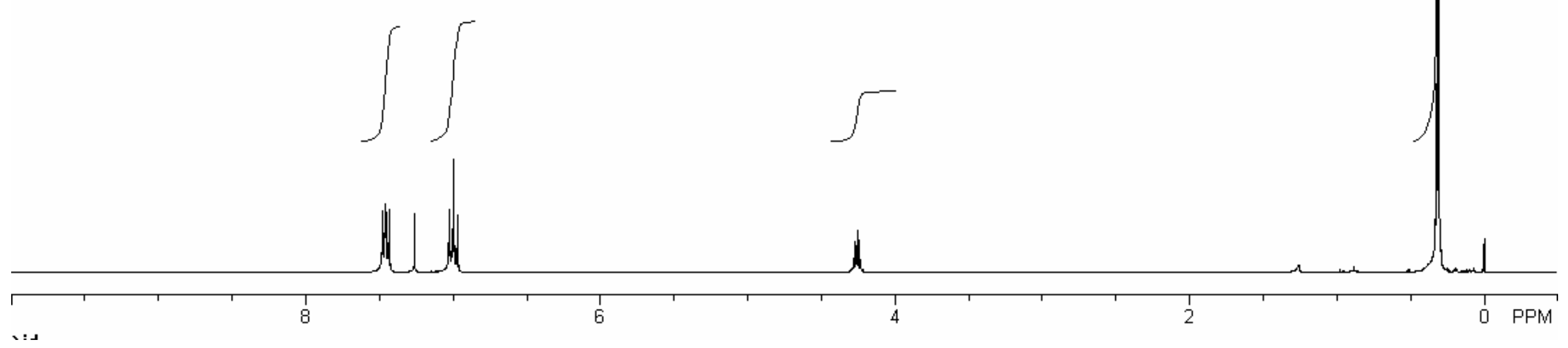




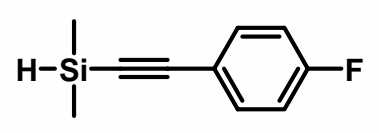

Compound 12d

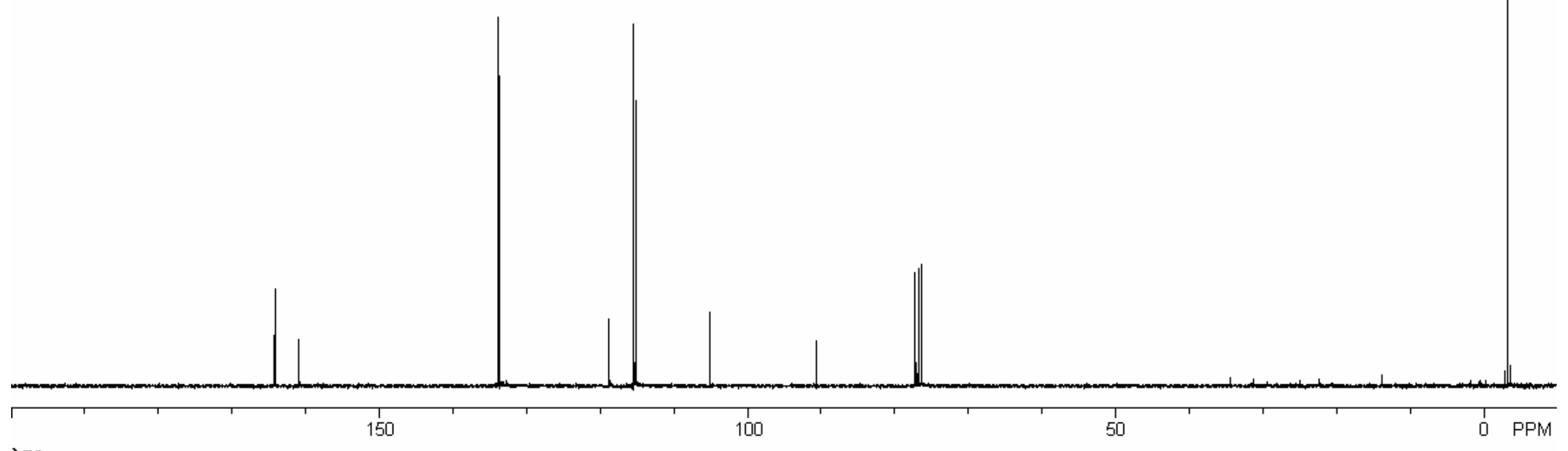




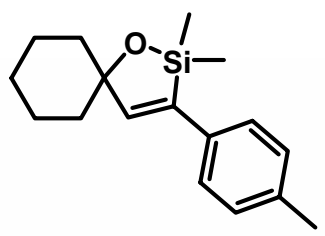

Compound 13c

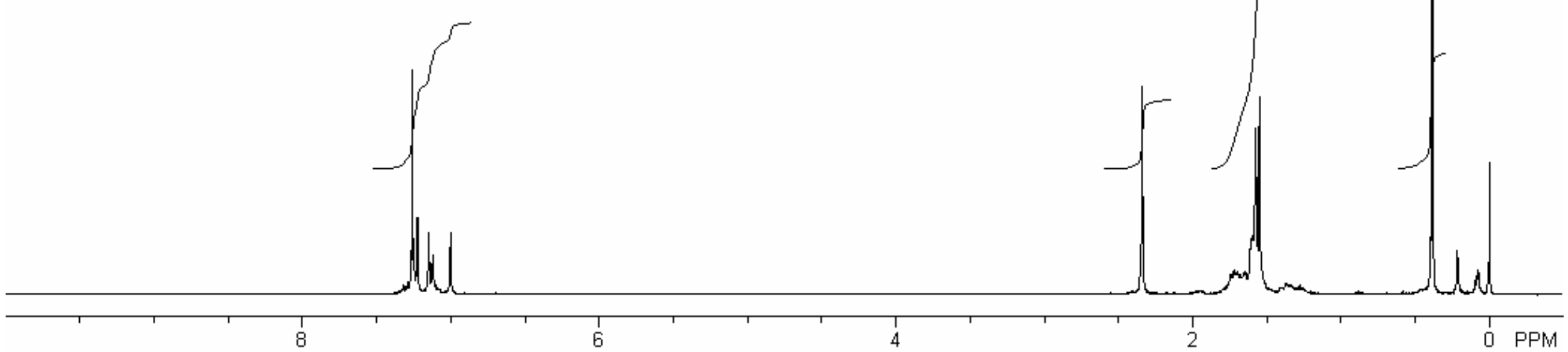

7

S47 
compound 13c

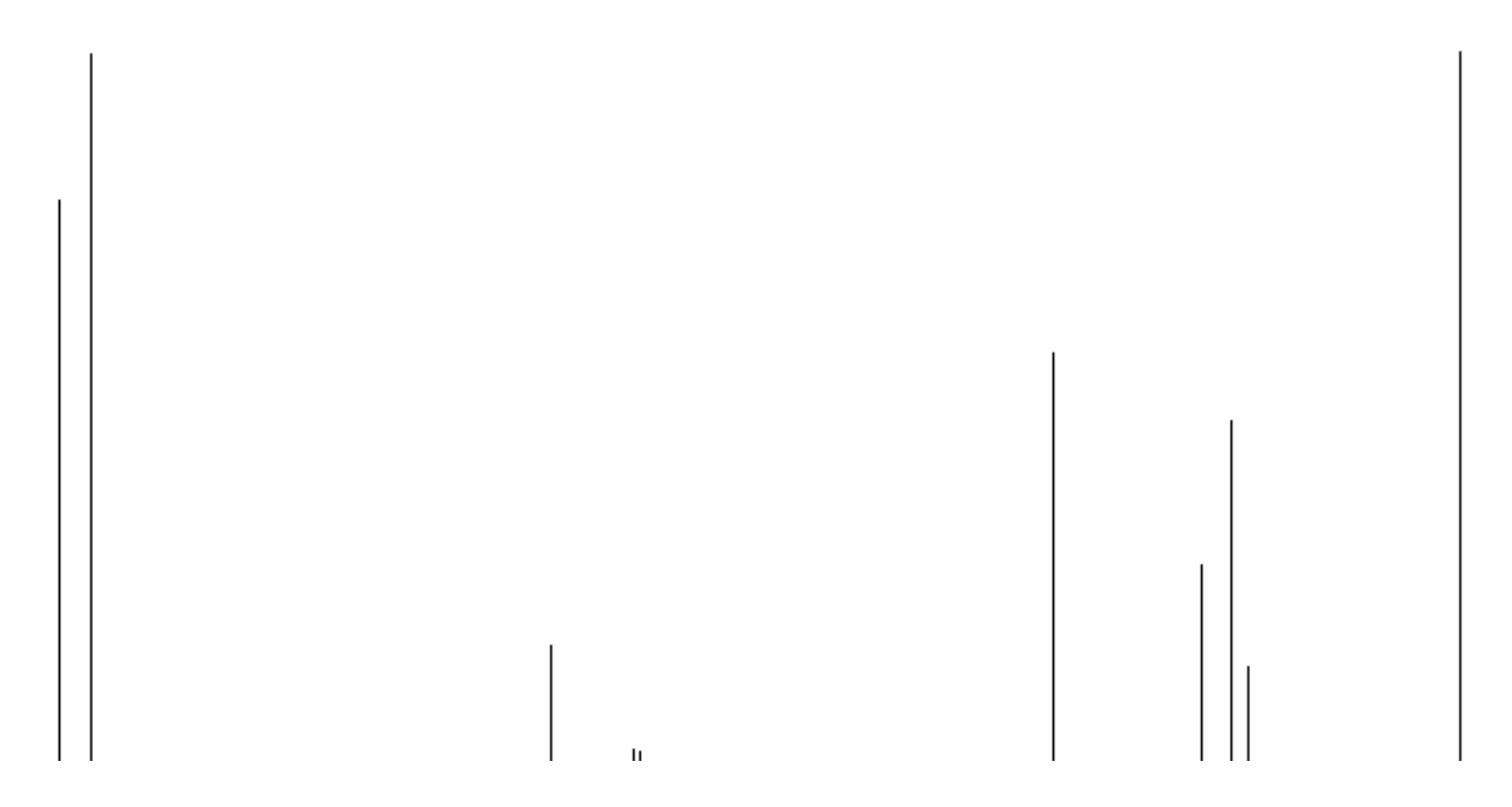

$$
=Q_{2}^{0.9-1}
$$


Compound 13d

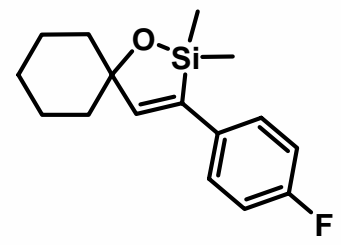

Compound 13d 


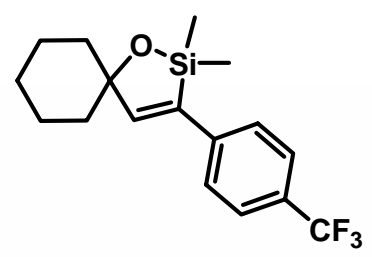

Compound 13e 


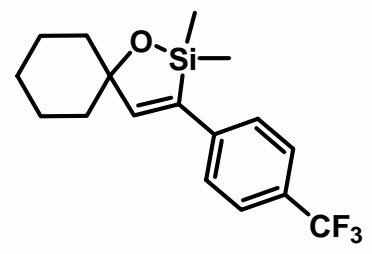

Compound 13e 


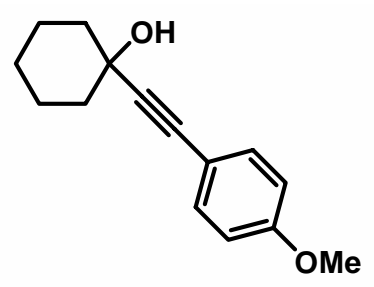

Compound 14a 


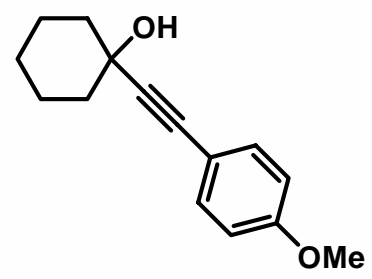

Compound 14a

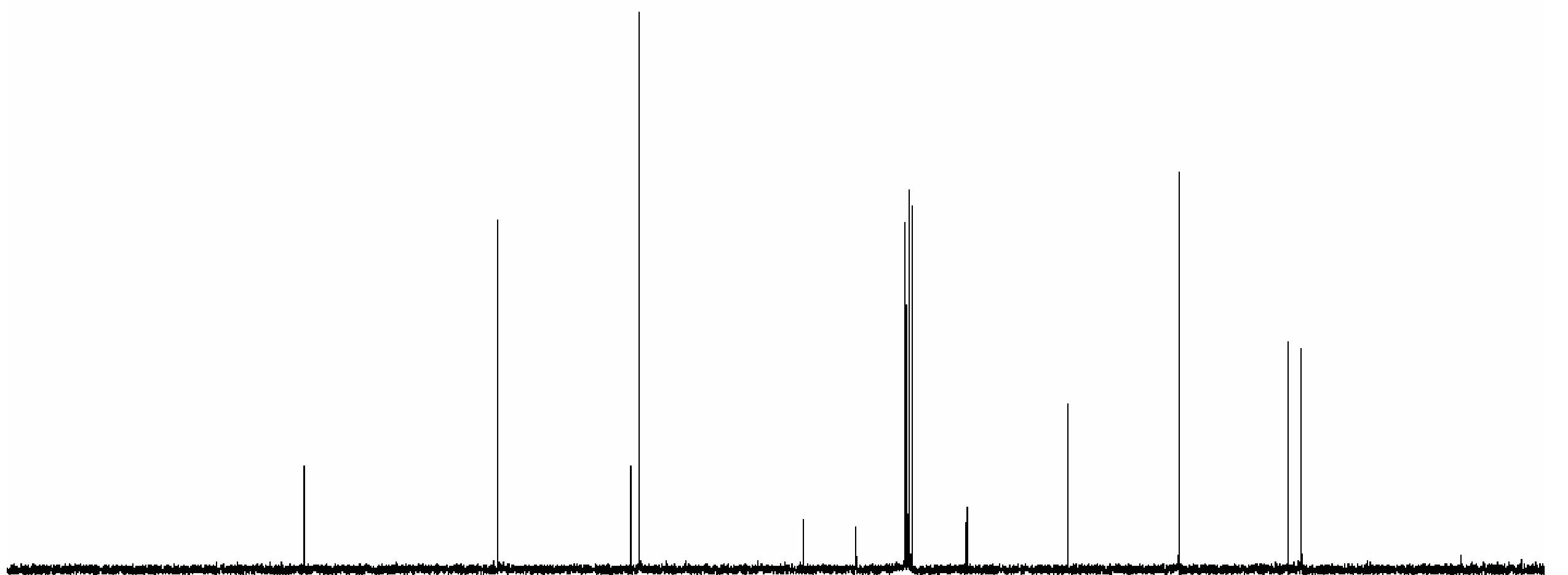




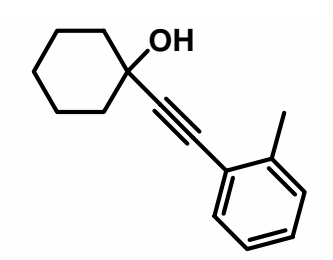

Compound 14b

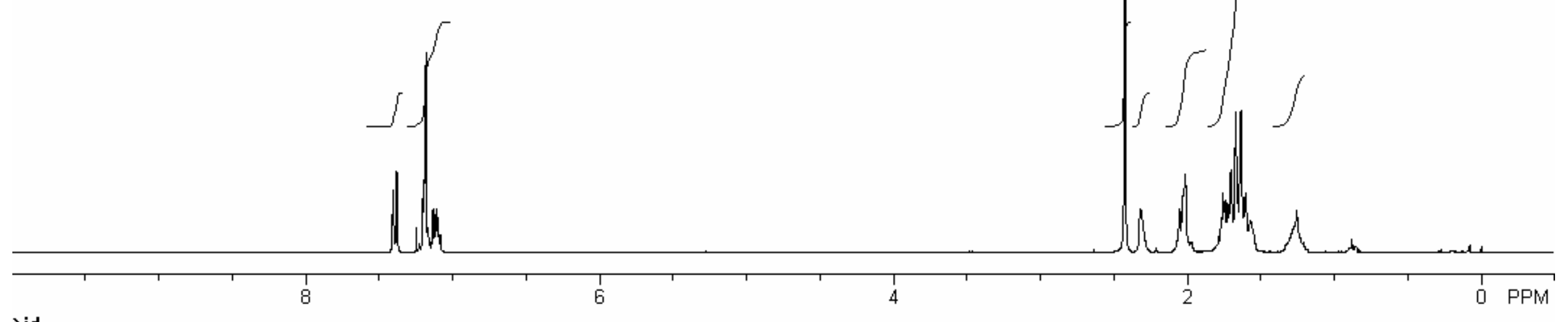




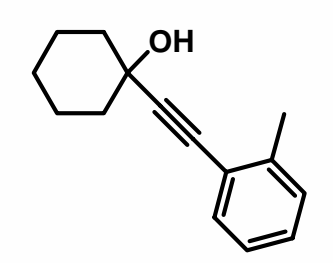

Compound 14b

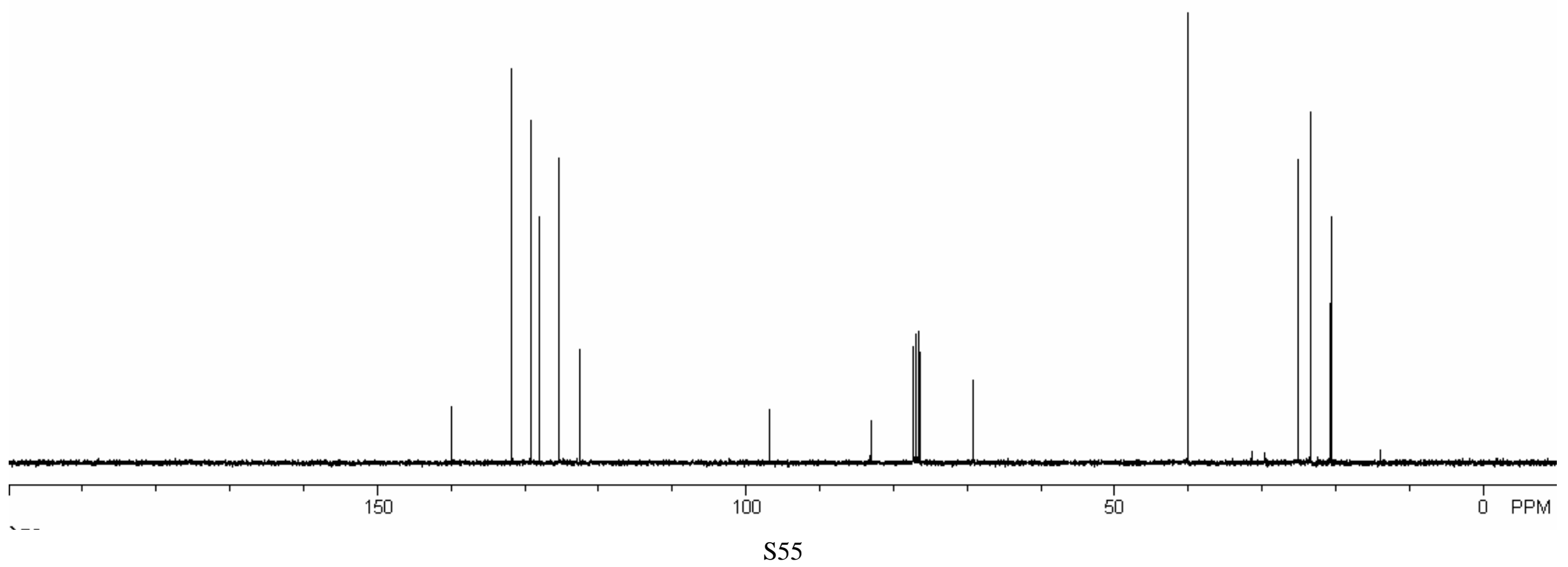




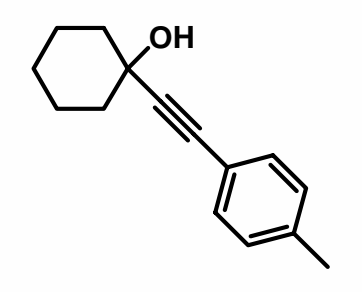

Compound 14c

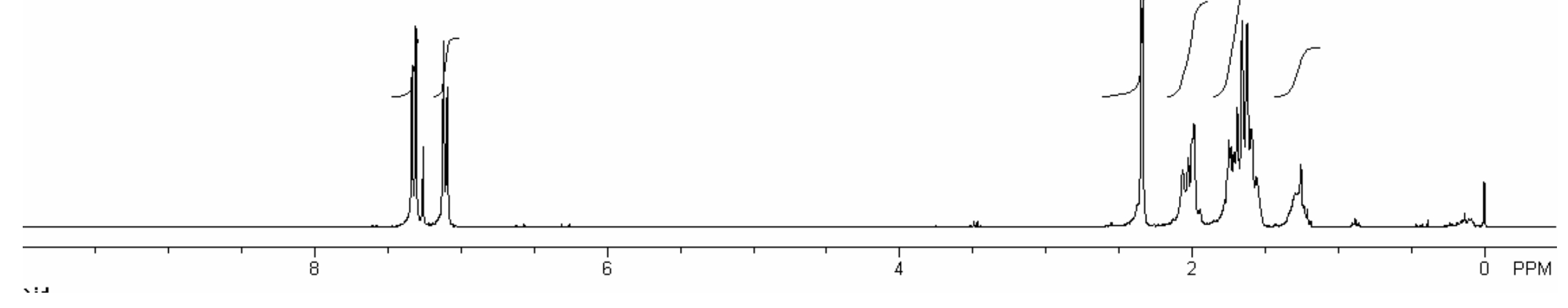




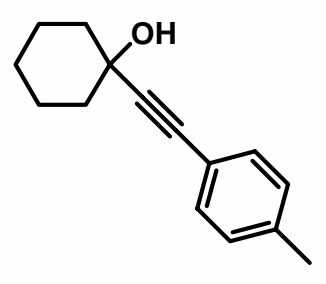

Compound 14c

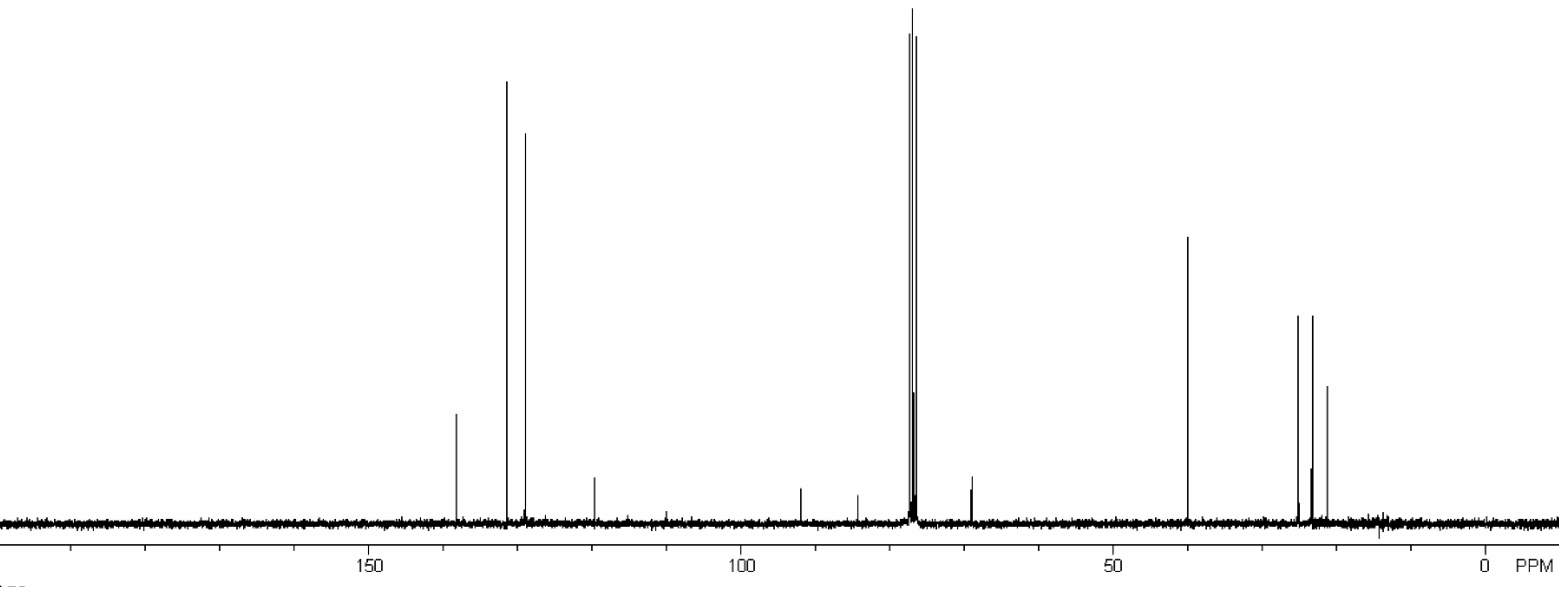




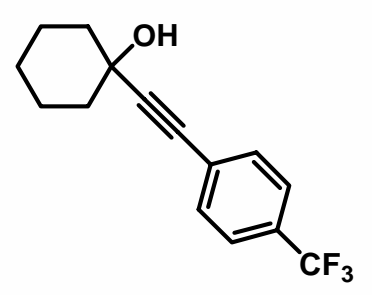

Compound 14e

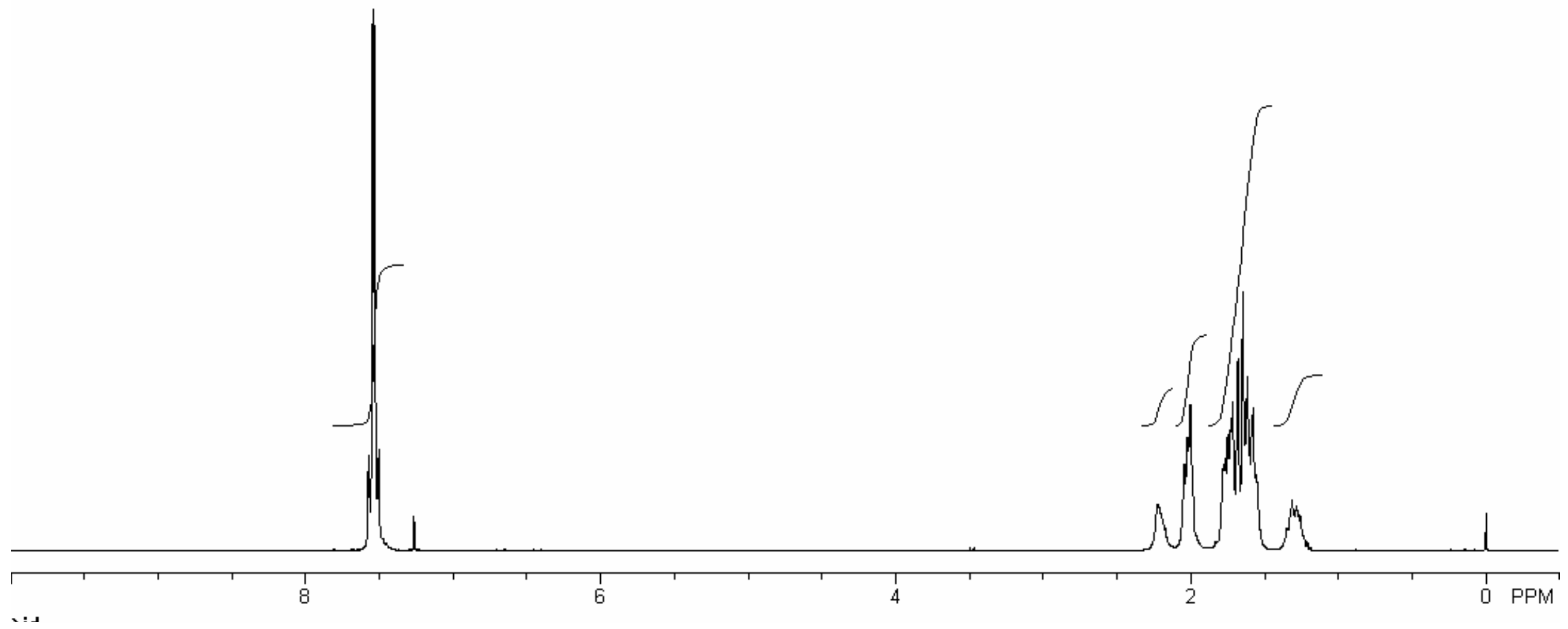




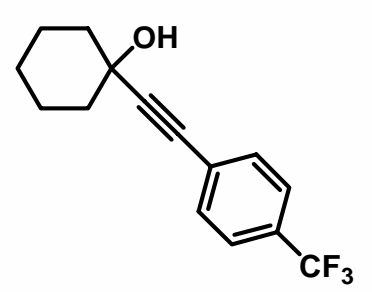

Compound 14e

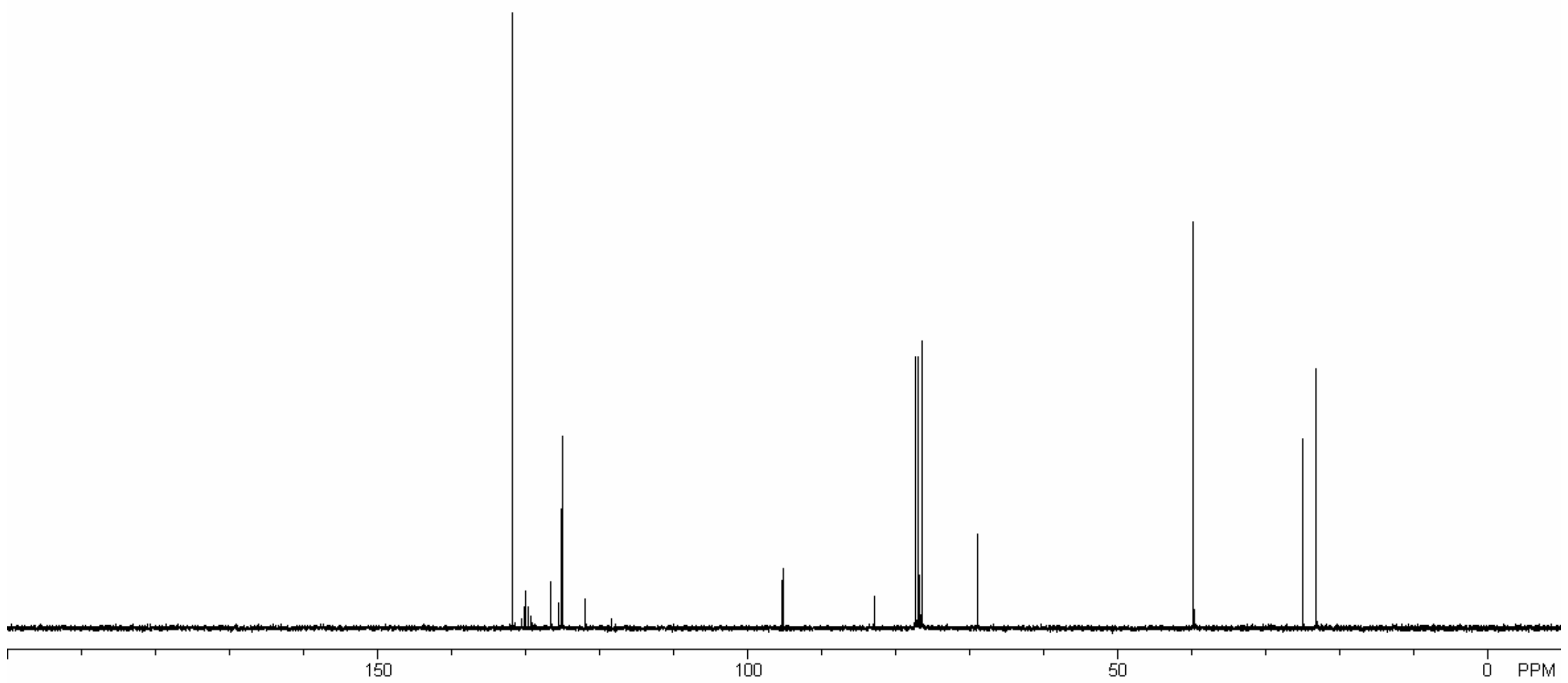




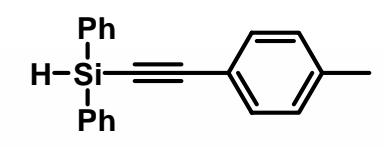

\section{Compound 17}

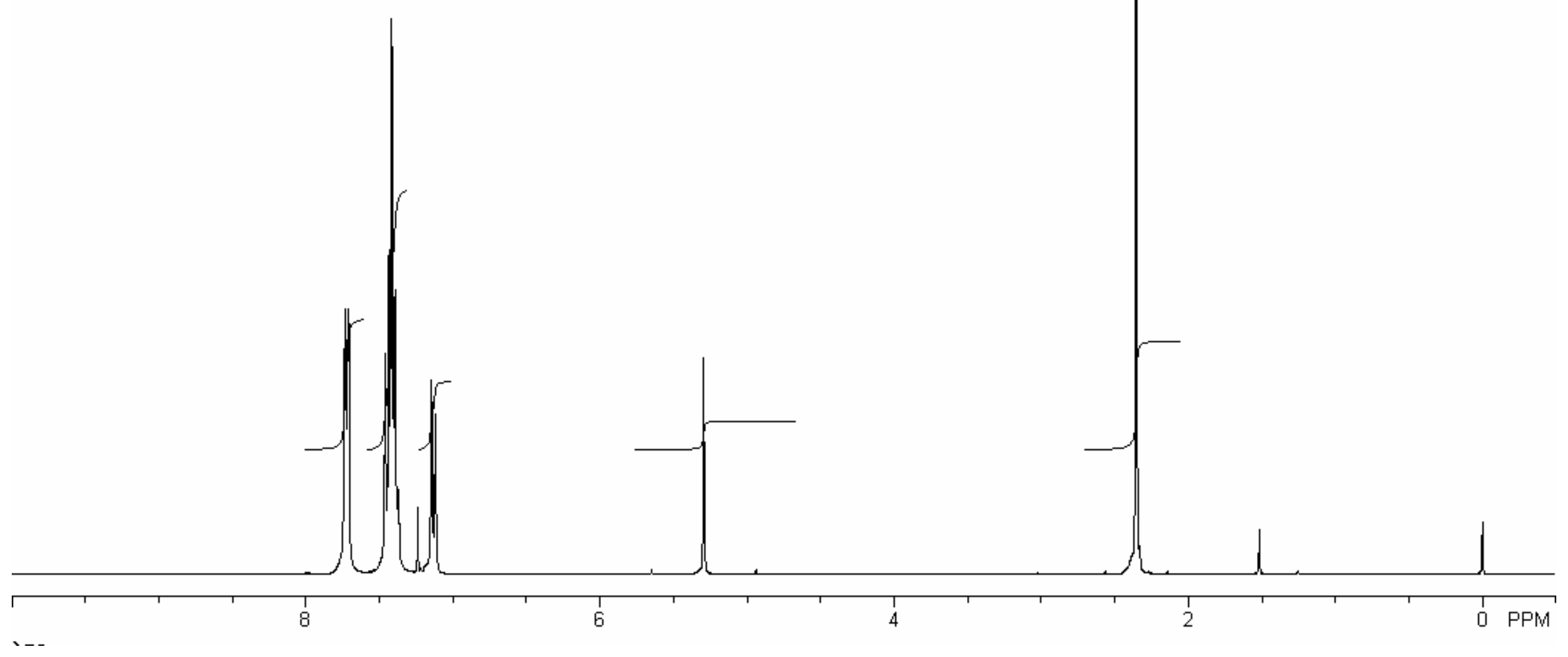




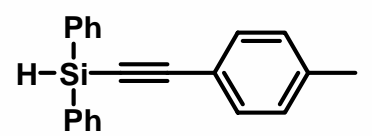

\section{Compound 17}

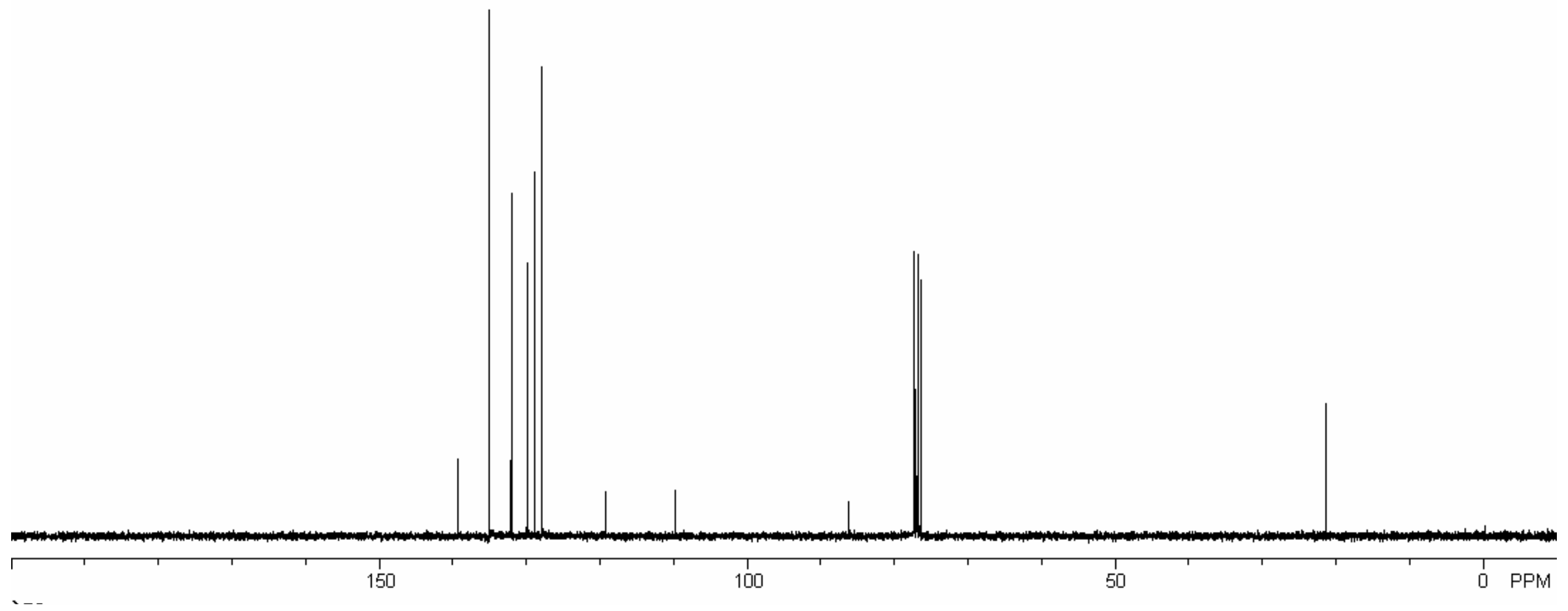




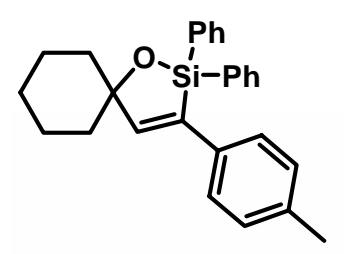

Compound 18

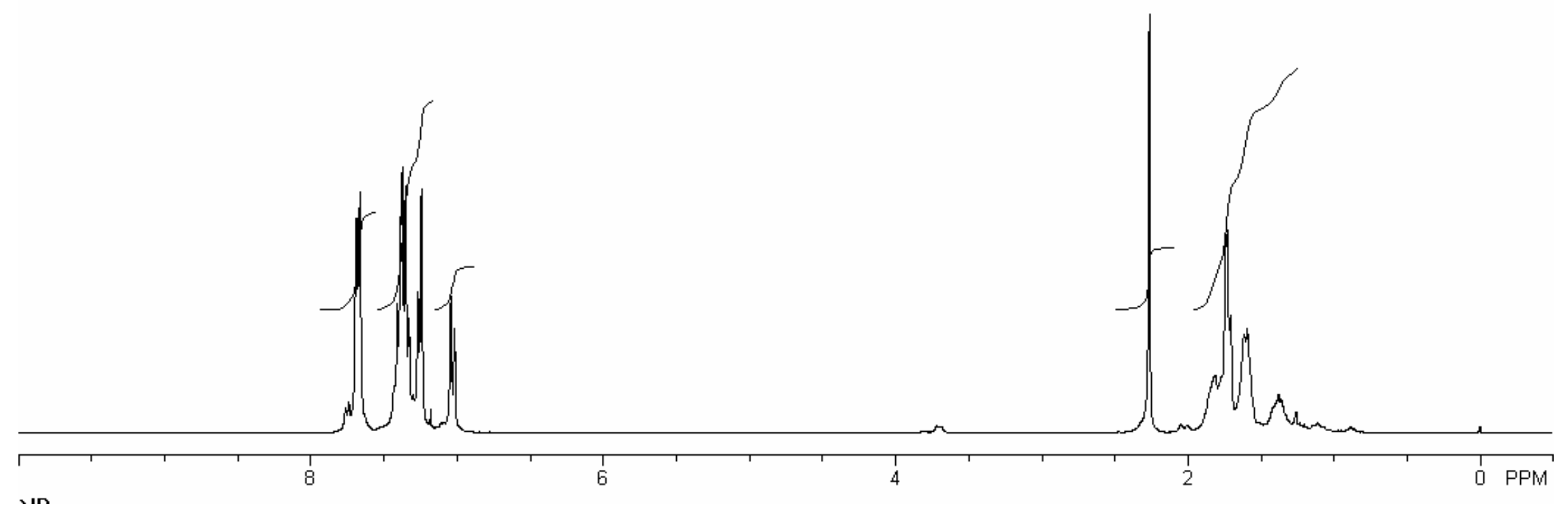

S62 


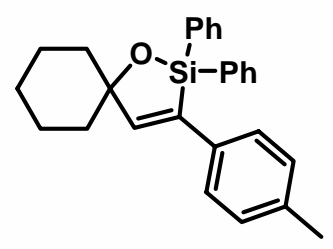

Compound 18

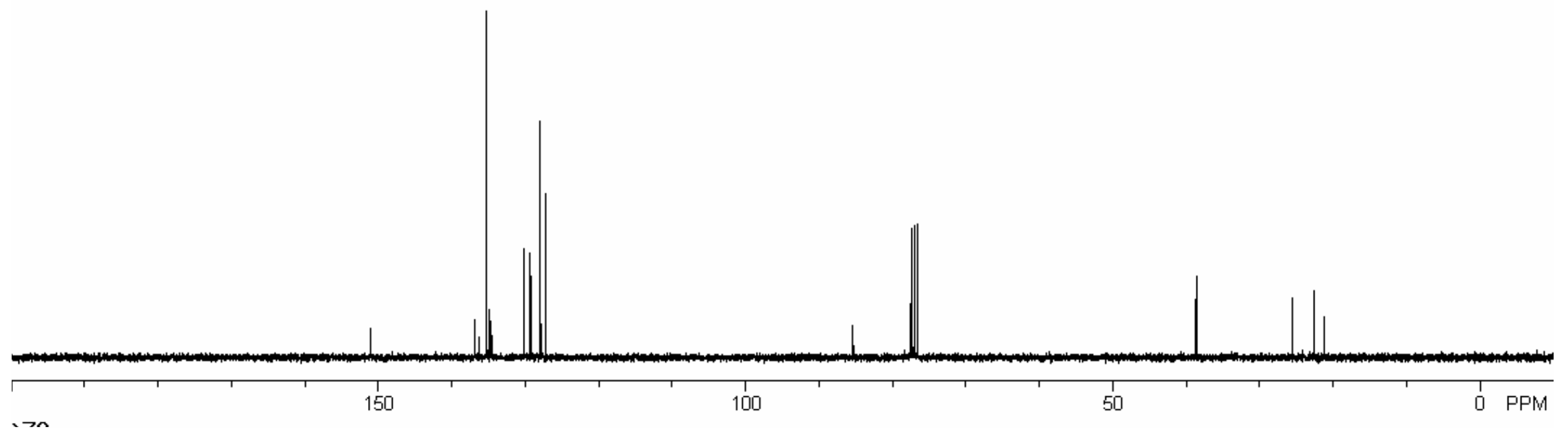

S63 


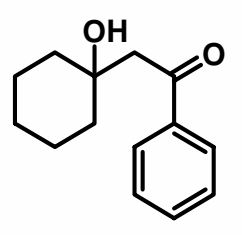

Compound 19

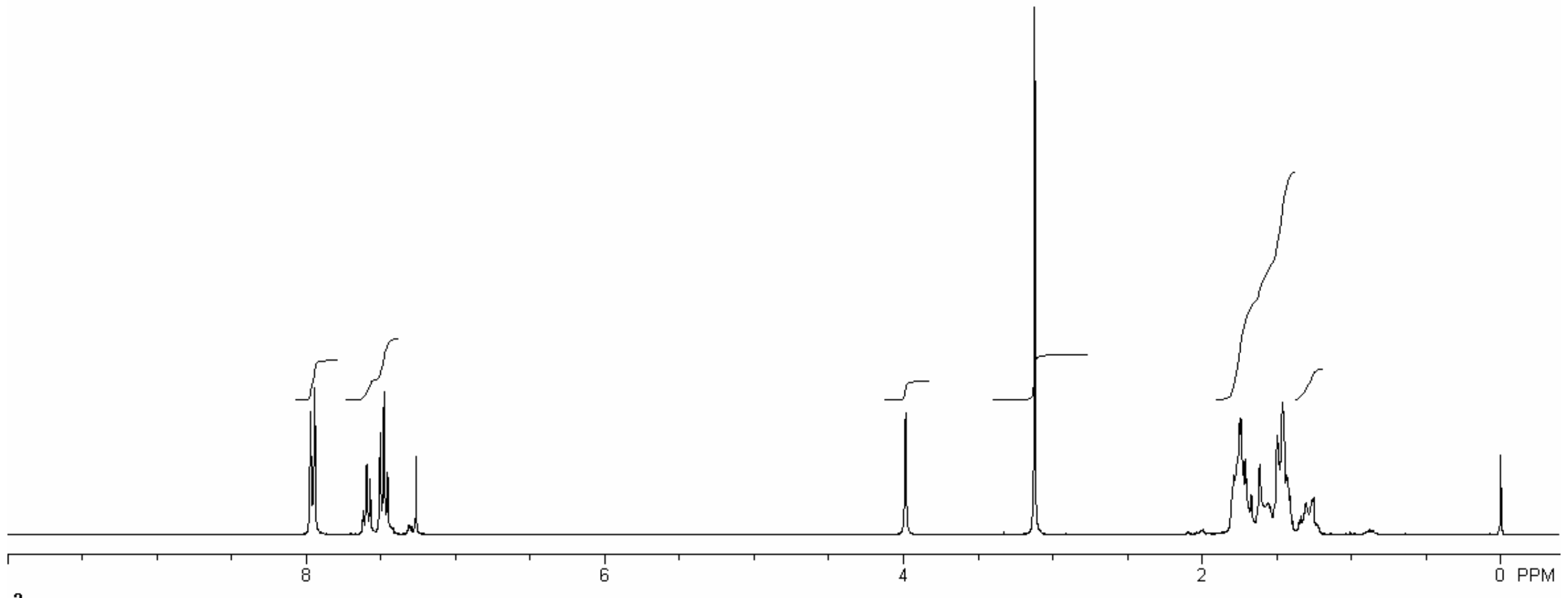




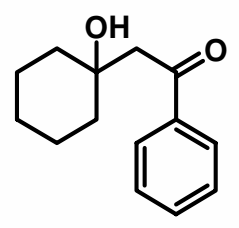

Compound 19

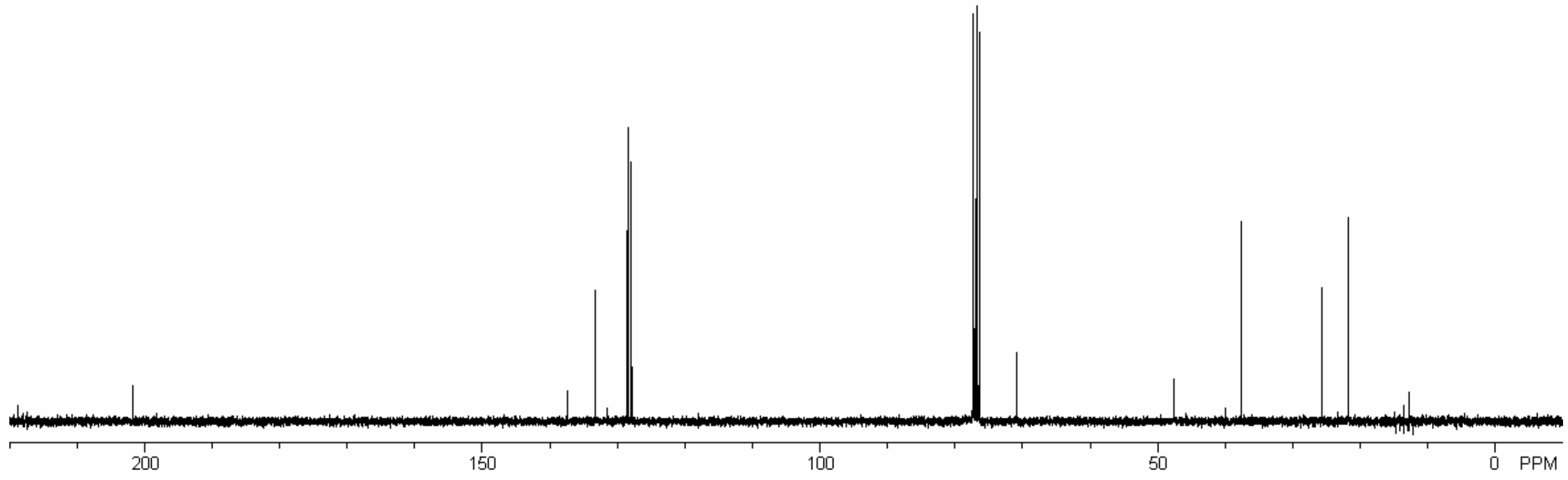




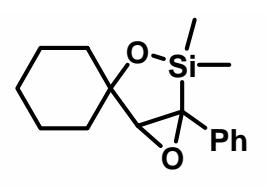

Compound 20

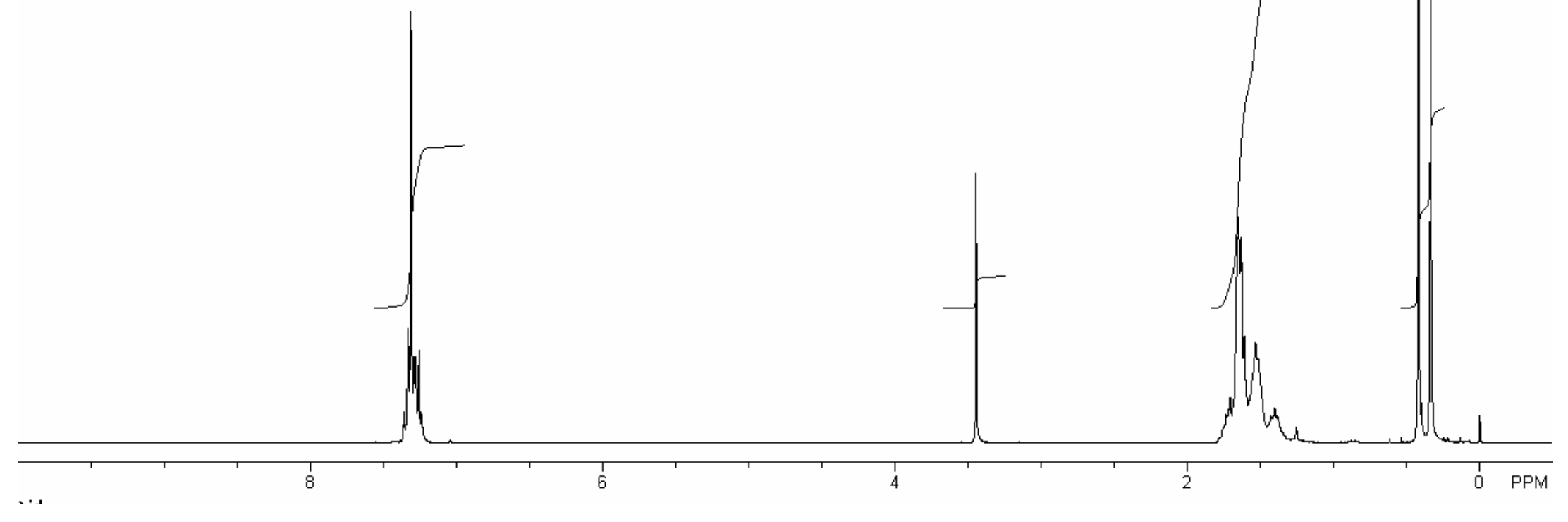




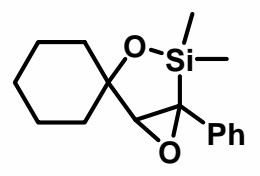

Compound 20

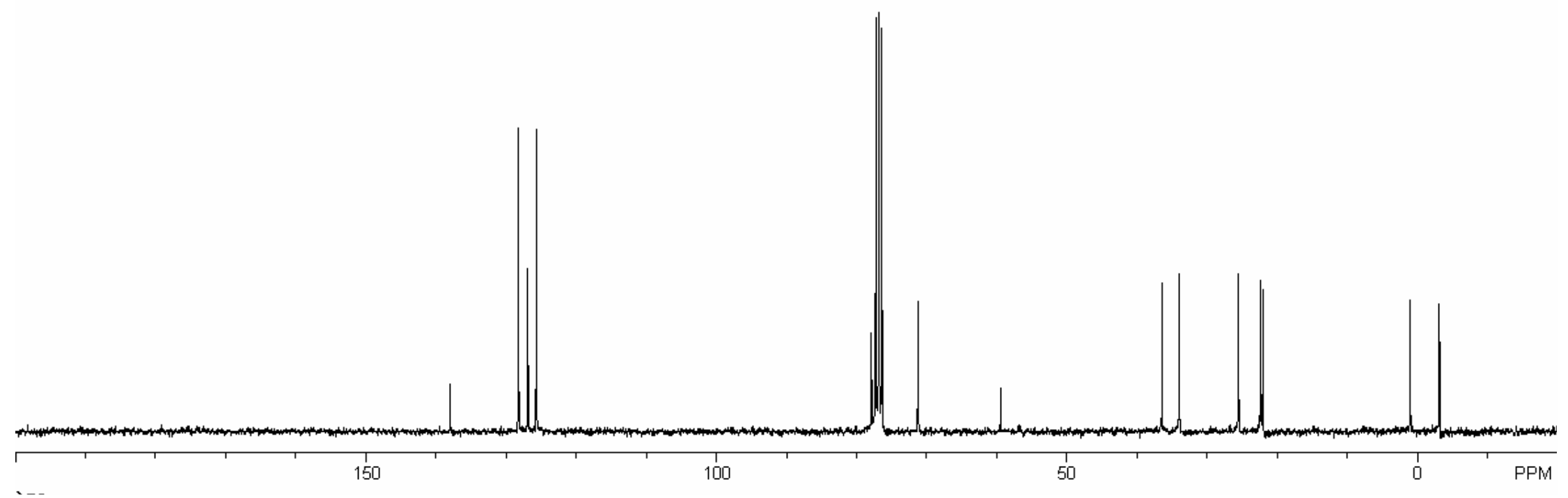




$$
\text { int }
$$




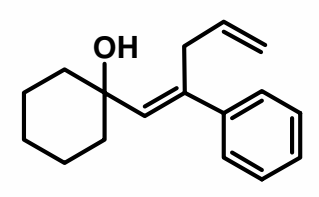

Compound 21

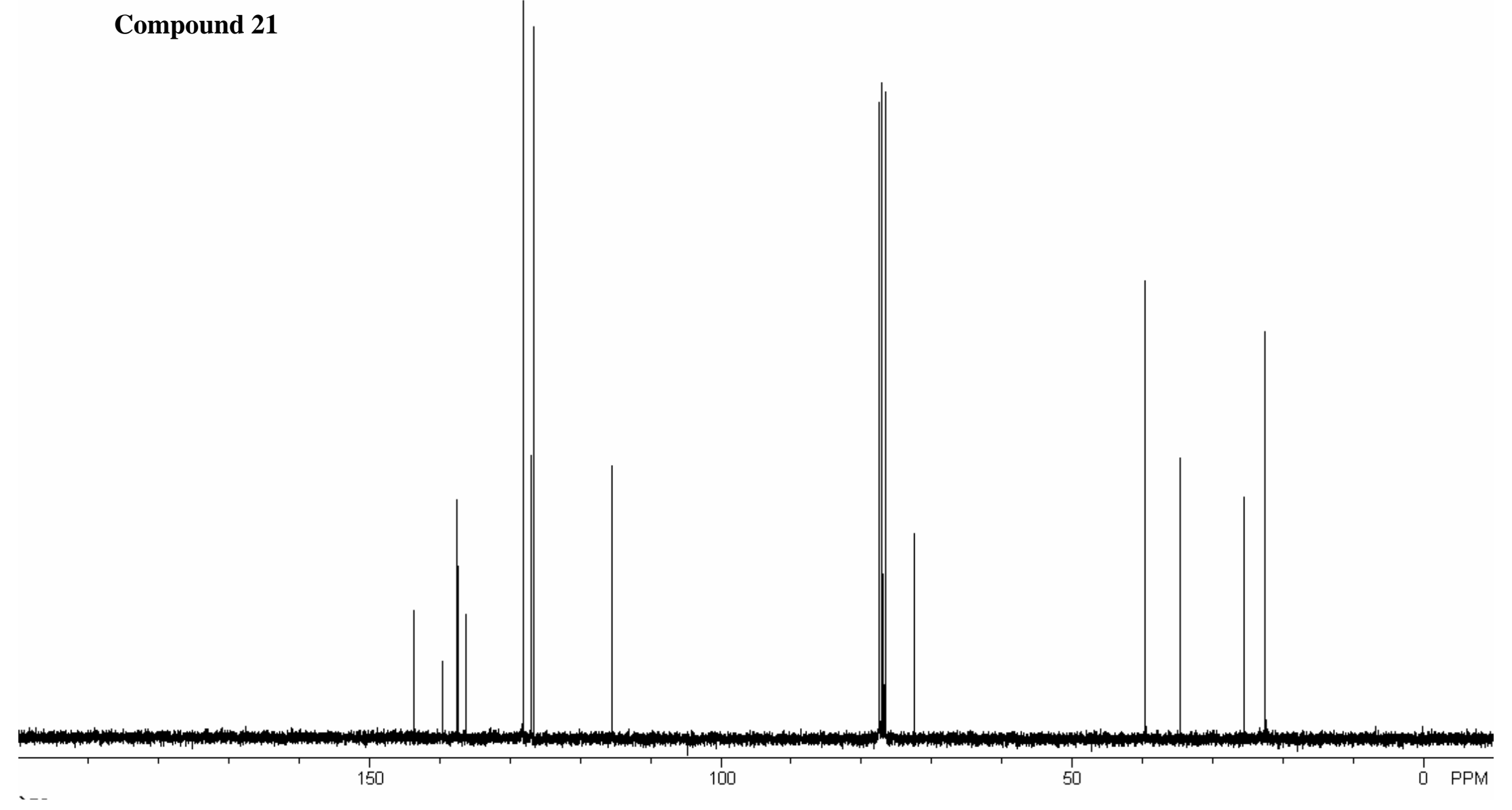




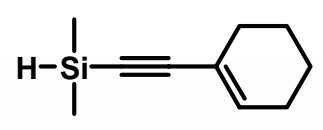

Compound 22

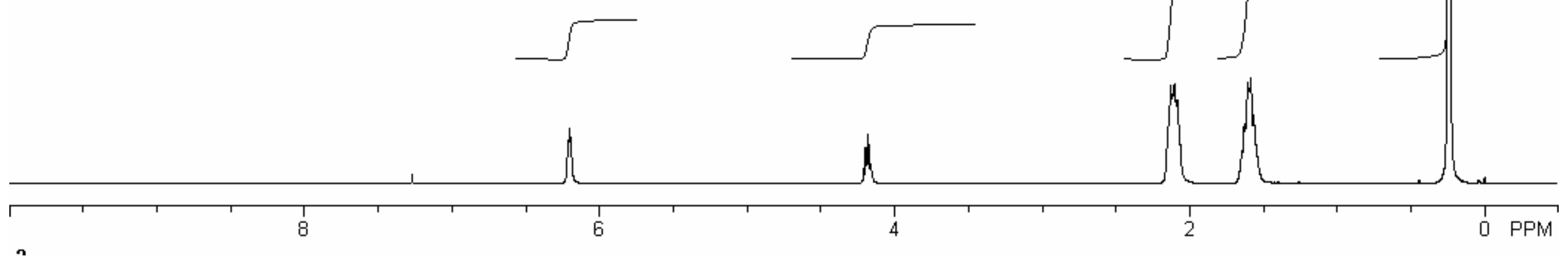




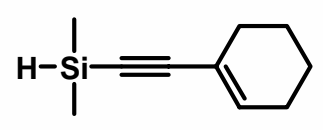

Compound 22

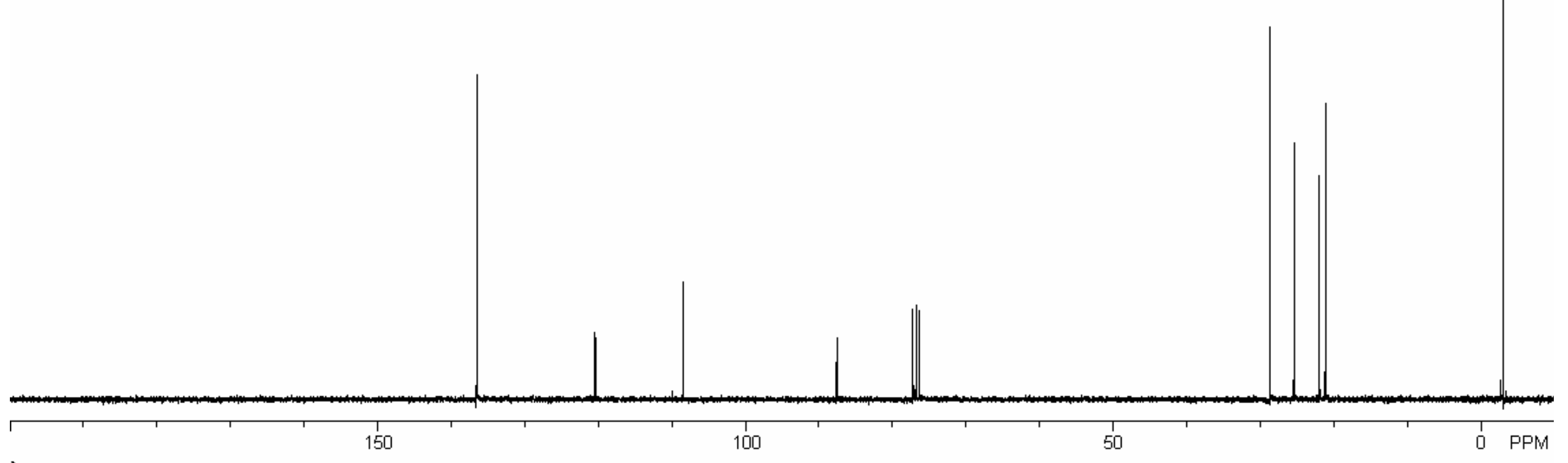




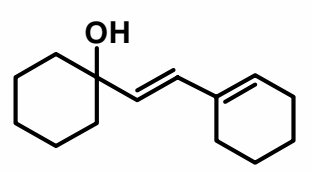

Compound 24

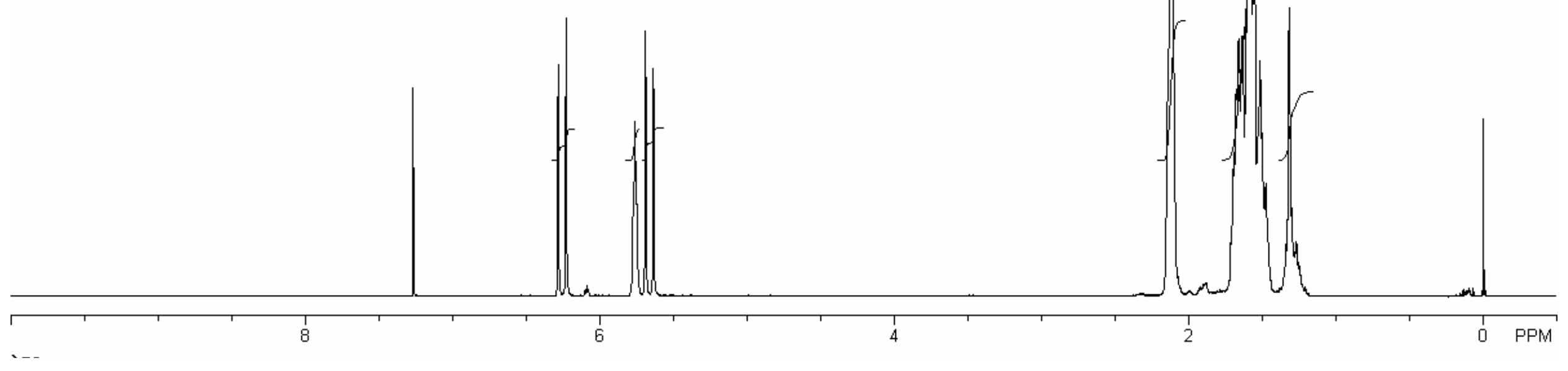




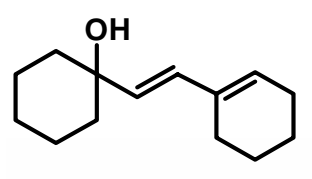

Compound 24

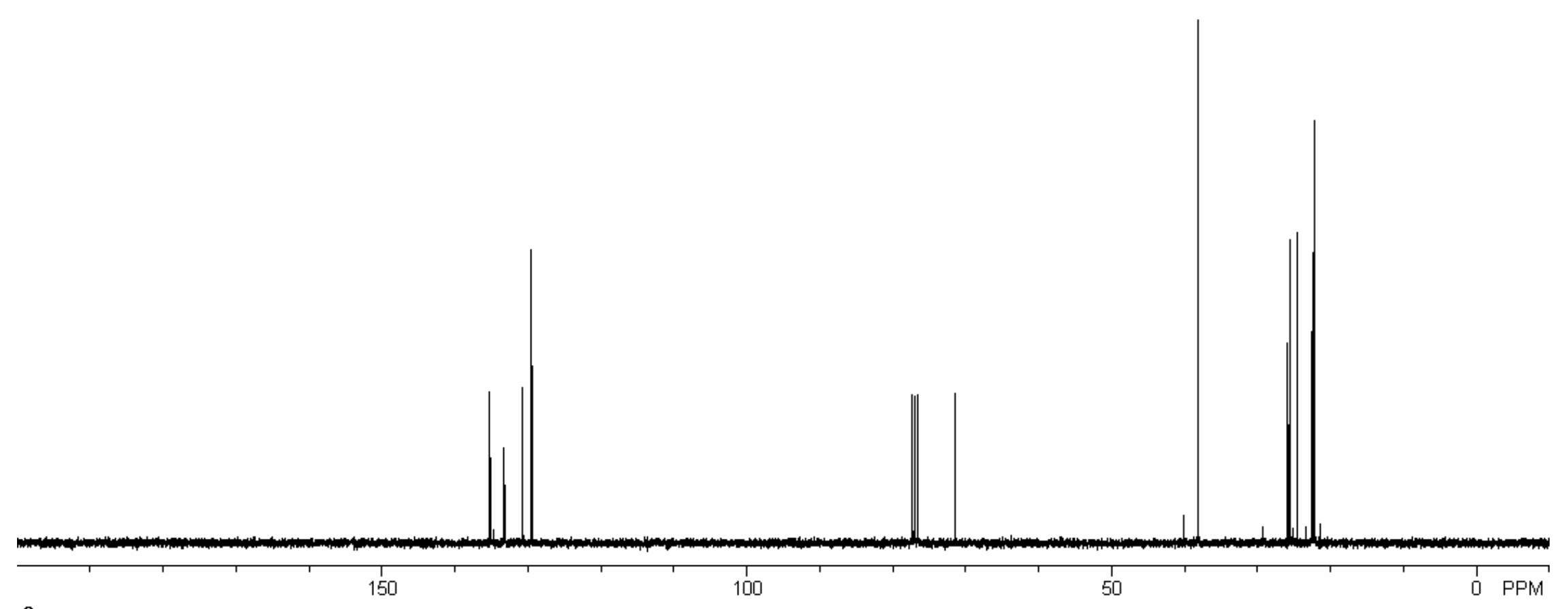

